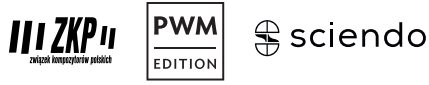

\section{A New Home Leads to Compositional Evolution: Roman Palester's Preludes for Piano (1954)}

\author{
BLAKE PARHAM \\ Independent Scholar, Australia - Poland \\ Badacz niezależny \\ 凶blakeparham@gmail.com
}

DOI: $10.2478 /$ prm-2021-0003

\section{Introduction ${ }^{1}$}

In the 1950 Western classical music was dominated by a divergent set of musical styles and compositional techniques, all of which were influenced and viewed through the prism of the Cold War which had enveloped the world. Richard Taruskin, when introducing his volume on the musical history of the second half of the $2 \mathrm{O}^{\text {th }}$ century, wrote:

The theme governing this volume's coverage is the cold war and its as yet insufficiently acknowledged (not to say tendentiously minimized) impact on the arts. The cold war was a period of political and cultural polarization - a polarization that is all too readily apparent in terms of musical style $[. . .]^{2}$

1 This article is based on work completed during the author's doctoral dissertation at the Sydney Conservatorium of Music. Blake Parham, “The Invisible Man: Roman Palester and His Place in Post-War Polish Music" (PhD diss., University of Sydney, 2020).

2 Richard Taruskin, "Preface - Music in the Late Twentirth Century". Oxford University Press. https://www.oxfordwesternmusic.com/view/Volume5/actrade-9780195384857-miscMatter-011008.xml. Accessed on $26^{\text {th }}$ June 2020.

Nowy dom sprzyja kompozytorskiej ewolucji: Preludia na fortepian Romana Palestra (1954)

(C) 2021 by Blake Parham. - This is an open access article licensed under the Creative Commons Attribution-ShareAlike International (CC-BY-SA 4.o) https://creativecommons.org/licenses/by-sa/. 
Additionally, the mid-20 ${ }^{\text {th }}$ century was plagued by several stylistic questions, principally an emphasis on atonality and modernisation. How was a composer to engage with these ideas, what technique(s) should he/she employ: twelve-tone, some other form of serialism, free-form atonality, aleatorism, or sonorism? Was the neo-classical style of Stravinsky now "played out" or could it be further developed? Should one ignore the apparent Western desire to modernise music and instead revert to more "tried and tested" compositional methods?

The Polish composer, Roman Palester (1907-1989) is a particularly intriguing character from this period. Lauded as a successor to Karol Szymanowski in Poland during the 1940 s but now separated from his roots and residing in the "free" West. How did a Polish émigré, a man who perhaps did not clearly belong to either side of the Cold War, fit into this "modern" world? Was his music driven by avant-garde trends and anti-communist sentiments, or perhaps he had been genuinely convinced by some of the more conservative, tonal and traditional aesthetics which dominated the Eastern Bloc at this time? Had Palester's compositional voice been greatly affected by his defection? This paper will examine one of Palester's pivotal compositions, written during a time of great political and personal upheaval, his Preludes for Piano (1954). The exploration of this work will provide a snapshot into how Palester reacted and interacted with the various musical styles, techniques, and cultural politics which dominated Europe during the 1950 .

\section{Biographical Data}

Before discussing Palester's Preludes for Piano, it is worth presenting some brief biographical information about that largely unknown composer. Roman Palester was one of the most promising and best-known composers in Poland during the inter-war period. Prior to WWII Palester composed several large-scale classical works, including the popular Taniec z Osmołody [Dance from Osmoloda] (1932), Symphony No. 1 (1934-1935), ${ }^{3}$

\footnotetext{
3 The score of this work was lost during World War II and the work was not reconstructed.
} 
Mata Uwertura [Little Overture] (1935), Concertino for Piano and Orchestra (1935-1936), ${ }^{4}$ his ballet Pieśn o Ziemi [Song of the Earth] (1937), and Concertino for Alto Saxophone and Strings (1938). His musical style at that time was underpinned by popular neo-classical ideals and folklorism with the addition of more progressive musical techniques towards the end of the decade. He also regularly composed music for film, radio and the theatre; writing music to no less than 40 theatrical productions between 1931 and 1939. ${ }^{5}$ Palester also composed a popular song entitled Baby, ach te baby [Oh Those Women] for the film Zabawka [Toy] (1933), which became wellknown in Poland. 6

During World War II Palester was arrested by the Gestapo on several occasions and was briefly sent to Pawiak prison in May 1940. ${ }^{7}$ Regardless of these persecutions, Palester continued to compose, writing a Violin Concerto (1939-1941), Symphony No. 2 (1941-1942), String Quartet No. 3 (1942-1944), Concertino for Piano and Chamber Orchestra (1942), Polonaises by Michat Kleofas Ogiński for chamber orchestra (1943), and Two Etudes for Piano (1943). He also began work on his Requiem (1945-1948), in response to the tragedy of the war.

After the war Palester moved to Kraków, where he was appointed a professor ${ }^{8}$ at the newly re-established Konserwatoium Krakowskie [Conservatorium in Krakow] and served as acting vice-rector ${ }^{9}$ of the conservatorium from $1945^{-1946 .}{ }^{10}$ During this period Palester was seen by many as one of the future compositional heavyweights in Poland. He was

4 Ibidem.

5 List provided in Zofia Helman, Lech Dzierżanowski, and Piotr Maculewicz, Roman Palester (Warszawa: Library of Warsaw University 2008) [Interactive Compact Disc].

6 Michał Waszyński, Zabawka (Falanga Film Studio, 1933).

7 Roman Palester, Stuch absolutny. Niedokończona autobiografia i listy z lat wojny [Perfect Pitch: Unfinished Autobiography and Wartime Letters], ed. Zofia Helman (Kraków: Polskie Wydawnictwo Muzyczne, 2017), s. 289.

8 "Protocols from the Senate Meetings," (Kraków Academy of Music Archives: Catalogue number: $90 / 27,31^{\text {st }}$ July $1945-28^{\text {th }}$ September 1949 ).

9 This title probably best equates to Deputy Director or Deputy Dean in the Anglo-university model.

10 "Protocols from the Senate Meetings." 
considered "the" composer in Kraków, being awarded the Nagroda Muzyczna Miasta Krakowa [City of Kraków Music Prize] in 1946,11 and was the equal runner up of the prestigious Szymanowski Composition Competition in $1948 .{ }^{12} \mathrm{He}$ was also made vice-chair of the national committee of the Związek Kompozytorów Polskich (ZKP) [Polish Composers' Union], chair of the Kraków branch of the $\mathrm{ZKP},{ }^{13}$ and was invited to be a juror for the Béla Bartók International Composition Competition in Budapest in $1948 .{ }^{14}$

Palester's compositions were regularly performed by all of Poland's orchestras and his music began to make a name for him abroad. In December 1946 his second symphony was performed in Paris by Grzegorz Fitelberg as part of a United Nations Educational, Scientific and Cultural Organisation event. ${ }^{15}$ Fitelberg conducted Symphony No. 2 again in the Hague and Rome in $1947 .{ }^{16}$ In that same year Palester's Sonatina for Piano for Four Hands was performed in England, ${ }^{17}$ and in 1948 his String Quartet No. 3 in the Netherlands. ${ }^{18}$ In fact, by 1948 his works had been performed in Paris, Venice, the Hague, Prague, Amsterdam, Copenhagen, London, Rome, Denmark, and Brussels.

11 Polskie Wydawnictwo Muzyczne, "Certificate to Commemorate Roman Palester Receiving the First Post-War Music Prize of the City of Kraków in 1946" (Warszawa: Biblioteka Uniwersytetu Warszawskiego - Library of Warsaw University: Polish Composers Archives, Palester Collection, $27^{\text {th }}$ October 1946).

12 The competition was won by Andrzej Panufnik, while Palester was awarded equal second prize for his Nocturne for strings with Stanisław Skrowaczewski's Overture.

13 Krzysztof Bilica, "Palester Roman," in Polish Music. Polish Composers 1918-2010, ed. Marek Podhajski (Gdańsk: Akademia Muzyczna im. Stanisława Moniuszki, and Katolicki Uniwersytet Lubelski Jana Pawła II , 2013).

14 Ibidem.

15 Grzegorz Fitelberg to Roman Palester. Letter Collection from 1945 to 1950 (Library of Warsaw University: Polish Composers Archives, Palester Collection).

16 Ibidem.

17 Czesław Halski to Roman and Barbara Palester. Letter Collection from $29^{\text {th }}$ January 1947 to $27^{\text {th }}$ September 1951 (Library of Warsaw University: Polish Composers Archives, Palester Collection).

18 Ibidem. 
Palester's place at the vanguard of Polish music was well known abroad, as noted in the Italian publication Musica: "Roman Palester is one of the most representative composers of the young Polish generation and his works obtained a brilliant success abroad." 19 Similar statements were made in Peurquei-Pas in Brussels: "Roman Palester, one of the most original talents of modern Poland" 20 and the Czech publication Lidové Noviny: “...Roman Palester, the most prominent personality of the musical Poland of today gave us the delicious Divertimento for Nine Instruments full of charm in its rhythm and in its sound..." 21

In the end the most significant international endorsement of Palester's abilities was probably made by the famed teacher of composition, Nadia Boulanger (1887-1979) who in 1946 wrote: "R. Palester is a musician who has a lot to say. He has produced the most striking works." 22

Seemingly on the verge of international stardom and at the peak of his fame in Poland, Palester made the decision to take up a second residence in Paris in 1947. It was at this time that Palester began to experiment with twelve-tone technique, albeit still using a number of neo-classical techniques. This led some commentators and musicologists to label many of his works from this period as "neo-classical dodecaphonic" works. ${ }^{23}$

Following the tightening of controls and the official introduction of the state-sanctioned musical doctrine of socialist realism in 1949, Palester's relations with the Polska Rzeczpospolita Ludowa [Polish People's Republic]

19 "Roman Palester," Muzyka (May 1947). Cited and translated in Various, "Press Clippings Collected by the Composer and Held in His Personal Archives," (Library of Warsaw University: Polish Composers Archives, Palester Collection, 1930-1990).

20 "Review of Belgian Radio Orchestra Concert," Pourquoi-Pas (21 October 1949). Cited and translated in Various, "Press Clippings Collected by the Composer and Held in His Personal Archives."

21 "Roman Palester," Lidové Noviny (2 June 1948). Cited and translated in Various, "Press Clippings Collected by the Composer and Held in His Personal Archives."

22 Nadia Boulanger, "Roman Palester," Spectateur (17 December 1946). Cited and translated in Various, "Press Clippings Collected by the Composer and Held in His Personal Archives."

23 Jadwiga Paja-Stach, Polish Music from Paderewski to Penderecki (Kraków: Musica Iagellonica, 2010). 
further deteriorated. After the Polish regime refused to pay Palester royalties in late 1950, he was forced to resign his membership of the Związek Autorów i Kompozytorów Scenicznych [Polish Society of Authors and Composers] (ZAiks) on the $2 \mathrm{O}^{\text {th }}$ of March 1951 and joined the Société des Auteurs, Compositors et Éditeurs de Musique [The French Society of Authors, Composers and Music Publishers] in Paris. ${ }^{24}$ Once Palester made this decision, the Polish communist regime dealt swiftly and harshly with him. All ties with Palester were severed: his name was removed from publications, publishers' catalogues and film credits; his existing scores were ordered destroyed, and his memberships in any Polish society, including the ZKP, were revoked. Palester essentially disappeared from Polish society, and Polish musical history.

After his official defection and blacklisting in 1951 Palester did not compose much, writing Trois Sonnets à Orphée in 1952, ${ }^{25}$ Passacaglia in $1953,{ }^{26}$ and a set of ten Preludes for Piano in $1954 .{ }^{27}$ These works show additional development in Palester's use of twelve-tone technique, with the majority of the compositions' pitch material relating to the tone row. At this point Palester's compositions could no longer be labelled neo-Classical. However, he continued frequently to use classical period forms as a vehicle for his more dodecaphonic content.

\section{Preludes for Piano - Structure}

In Figure 1 a structural overview of the Preludes for Piano has been provided. In this table the various preludes and their constituent sections, the

\footnotetext{
Związek Autorów i Kompozytorów Scenicznych to Roman Palester. Letter Collection from 1949 to 1979 (University of Warsaw Library: Polish Composers Archives, Palester Collection).

25 Roman Palester, Trois Sonnets à Orphée (University of Warsaw Library: Polish Composers Archives, Palester Collection, 1952).

26 Passacaglia (University of Warsaw Library: Polish Composers Archives, Palester Collection, 1953).

27 Preludes for Piano (New York: Southern Music Publishing, 1963).
} 
page and line numbers for these sections (the cycle has no bars nor bar numbers), and the tempo are provided. The final column labelled "dynamic envelope" is a free graphical representation of the climactic points of the work as selected by the author using volume and density as determining factors. ${ }^{28}$ These graphical representations are, of course, subjective in nature and have not been determined using a statistical analysis or a formula. The graphical representation of the work's dynamic envelope aims to provide the reader with a sense of the work's dynamic and dramatic trajectory in relation to the work's constituent sections.

This table shows that all of the preludes are based either on a repeated first section or are through-composed. ${ }^{29}$ Some of the later preludes use a structure which requires the repeated revision of the first section. Prelude viII for example consists of an initial statement of the first section, a partial repeat of this section and at its conclusion a full repeat of the first section. Often when the first section returns at the conclusion of a Prelude it is played in almost exact repetition. Even when alteration of the original section does occur it is minor: a phrase is played in reverse, the left and right hands switch parts or an ascending phrase is played in a descending form.

The contrast of tempi between each movement is another notable structural component of this work, with Palester dividing the set equally into fast and slow movements. Preludes I, III, VI, and IX are all slow, under 66 beats per minute. Conversely, Preludes II, IV, VII, and VIII are fast, all above 90 beats per minute, while Prelude $X$ has both a fast and slow section. The only prelude to go against this trend is Prelude $\mathrm{V}$, which is neither markedly fast nor slow.

28 The graphical representation of the work's dynamic envelope used here follows the technique employed by Mikołaj Blajda in Mikołaj Blajda, "Roman Palester - Requiem. Analiza i interpretacja dzieła" [Roman Palester - Requiem Analysis and Interpretation of the Work] (Kraków: Akademia Muzyczna w Krakowie, 200o).

29 Preludes I, II, III, and VII. 
Figure 1. Preludes for Piano: Structural overview table

Piano Preludes - Overview

\begin{tabular}{llll}
\hline I & & & \\
Sections & Pages & Line & Tempo \\
& 3 & $1-2$ & Lento grave, poco rubato \\
Section 1 & 3 & $2-4$ & Passionato \\
& 3 & 4 & Grave, intenso \\
\hline
\end{tabular}

II

$\begin{array}{lcccc}\text { Sections } & \text { Pages } & \text { Line } & \text { Tempo } \\ \text { Section 1 } & 4 & 1-5 & \\ \text { Section 1 (repeated } & 5 & 1-5 & \text { Vivace } \\ \text { with slight alterations) } & 5 & 6 & \\ \text { Coda } & 5\end{array}$

III

\begin{tabular}{lllll} 
Sections & Pages & Line & Tempo & Dynamic Envelope \\
Section 1 & 6 & $1-2$ & Lento espressivo \\
& 6 & $3-4$ & Meno \\
\hline
\end{tabular}

IV

\begin{tabular}{lllll} 
Sections & Pages & Line & Tempo & Dynamic Envelope \\
Section 1 & 7 & $1-3$ & Agitato \\
Section 2 & $7-8$ & $3-3$ & Poco meno \\
Section 3 & $8-9$ & $4-2$ & Poco meno \\
Section 4 & 9 & $2-4$ & Agitato (Tempo 1) \\
\hline
\end{tabular}




\begin{tabular}{lcclll}
\hline $\mathbf{v}$ & & & & Duration: 2:30 \\
Sections & Pages & Line & Tempo & Dynamic Envelope \\
Section 1 & 10 & $1-4$ & Larghetto \\
Section 2 & $10-11$ & $4-2$ & Mosso \\
Section 1 (revised) & 11 & $3-5$ & Larghetto (Tempo 1) \\
\hline
\end{tabular}

\begin{tabular}{lllll}
\hline VI & & & & Duration: 2:05 \\
Sections & Pages & Line & Tempo & Dynamic Envelope \\
\hline Section 1 & 12 & $1-2$ & Largo pesante \\
Section 2 & Segment A & 12 & $3-4$ & \\
& Segment B & 13 & $1-2$ & Poco meno, rubato \\
Section 1 (revised) & & 13 & $2-4$ & Largo pesante (Tempo 1) \\
\hline
\end{tabular}

\begin{tabular}{|c|c|c|c|c|}
\hline VII & & & & Duration: 1:40 \\
\hline Sections & Pages & Line & Tempo & Dynamic Envelope \\
\hline Section 1 & $14^{-15}$ & & Andantino & \\
\hline
\end{tabular}

\section{VIII}

Duration: 1:10

\begin{tabular}{lcccc|l} 
Sections & Pages & Line & Tempo & \multicolumn{2}{c}{ Dynamic Envelope } \\
\hline Section 1 & 16 & $1-2$ & & \\
Section 2 & 16 & $3-4$ & Allegretto & \\
Section 1 (partial revision) & $16-17$ & $4-1$ & & \\
Section 3 & 17 & $2-4$ & Poco meno & \\
Section 1 (full revision) & 18 & $1-4$ & & \\
\hline
\end{tabular}




\begin{tabular}{|c|c|c|c|c|c|}
\hline \multicolumn{5}{|l|}{ IX } & \multirow{2}{*}{$\begin{array}{l}\text { Duration: 2:20 } \\
\text { Dynamic Envelope }\end{array}$} \\
\hline Sections & & Pages & Line & Tempo & \\
\hline \multirow{2}{*}{ Section 1} & Segment A & 19 & $1-3$ & Lento & \\
\hline & Segment B & $19-20$ & $4^{-1}$ & Piu vivo, passionato & \\
\hline Section 2 & & $20-21$ & $2-1$ & Molto cantabile & \\
\hline Section 3 & & 21 & $1-4$ & Mosso & \\
\hline
\end{tabular}

$\mathbf{x}$

\begin{tabular}{llllll|l} 
Sections & & Pages & Line & Tempo & \multicolumn{2}{c}{ Dynamic Envelope } \\
\hline & Segment A & 22 & $1-2$ & & \\
Section 1 & Segment B & $22-25$ & $2-2$ & Vivace & \\
& $\begin{array}{l}\text { Segment A } \\
\text { (revised) }\end{array}$ & 25 & $2-3$ & & \\
Section 2 & Segment A & $25-26$ & $4-1$ & Andante & \\
& Segment B & 26 & $1-4$ & Lento \\
\hline
\end{tabular}

\section{Palester's Approach to Writing with Twelve-Tones}

Palester's Preludes are challenging and virtuosic works, often requiring the pianist to play three or four dense and complex, yet independent parts at one time. Zofia Helman, et al. described Palester's Preludes for Piano as follows:

Ten miniatures composed in 1954 demonstrate a further development of Palester's dodecaphonic thinking. Throughout the cycle the composer uses only one series, applying it in inversion and in a variety of transpositions. However, Palester is far from consistent in his use of the serial technique. ${ }^{30}$

3o Helman, Dzierżanowski, and Maculewicz, Roman Palester. 
All ten of the Preludes use some form of twelve-tone technique, but to varying extents and in a variety of ways. There are some diatonically tonal moments in the work: Prelude $v$ for example uses very few twelve-tone techniques. The majority of the Preludes apply some deviation from a single row, as shown in Figure 2. There are, however, other twelve-tone sets in Prelude III, Prelude IX and Prelude X, which appear to be unrelated to the original row. Thus, while the ten preludes may be bound by their consistent use of twelve-tone technique, they do not rely solely on the same twelve-tone set.

In order to clearly articulate Palester's use of twelve-tone technique an analysis of each individual movement has been conducted and the findings detailed below. It is clear from this exploration that the work frequently calls on one twelve-tone row in particular, which has been labelled as the "original row" in this paper. This row was also identified by Helman in her analysis of the work. ${ }^{31} \mathrm{~A}$ tone matrix for this row has been provided in Figure 2.

Figure 2. Tone matrix for the original tone row in Preludes for Piano

\begin{tabular}{|c|c|c|c|c|c|c|c|c|c|c|c|c|c|}
\hline & 12 & 13 & 16 & 17 & 18 & 19 & 15 & I1 & 14 & |11 & |10 & 10 & \\
\hline P2 & D & D\# & F\# & G & G\# & A & $\mathrm{F}$ & C\# & $E$ & B & A\# & C & R2 \\
\hline P1 & $\mathrm{CH}$ & D & $\mathrm{F}$ & F\# & G & G\# & $\mathrm{E}$ & C & D\# & A\# & A & B & R1 \\
\hline P10 & A\# & B & D & D\# & $\mathrm{E}$ & $F$ & C\# & A & C & G & F\# & G\# & R10 \\
\hline P9 & A & A\# & C\# & D & D\# & E & C & G\# & B & F\# & $F$ & G & R9 \\
\hline P8 & G\# & A & C & C\# & D & D\# & B & G & A\# & $F$ & $E$ & F\# & R8 \\
\hline P7 & G & G\# & B & C & C\# & D & A\# & F\# & A & $\mathrm{E}$ & D\# & $\mathrm{F}$ & R7 \\
\hline P11 & B & C & D\# & $E$ & $\mathrm{~F}$ & F\# & D & A\# & C\# & G\# & G & A & R11 \\
\hline P3 & D\# & $E$ & G & G\# & A & A\# & F\# & D & $F$ & C & B & C\# & R3 \\
\hline PO & C & C\# & $E$ & $F$ & F\# & G & D\# & B & D & A & G\# & A\# & RO \\
\hline P5 & $\mathrm{F}$ & F\# & A & A\# & B & C & G\# & $E$ & G & D & C\# & D\# & R5 \\
\hline P6 & F\# & G & A\# & B & C & C\# & A & $F$ & G\# & D\# & D & $E$ & R6 \\
\hline P4 & $E$ & $F$ & G\# & A & A\# & B & G & D\# & F\# & C\# & C & D & R4 \\
\hline & RI2 & RI3 & RI6 & RI7 & RI8 & RI9 & RI5 & RI1 & RI4 & RI11 & RI10 & RIO & \\
\hline
\end{tabular}

31 Zofia Helman, Roman Palester. Twórca i dzieto [Roman Palester. The Artist and His Works] (Kraków: Musica Iagellonica, 1999). 
Prelude I presents various transpositions of prime and inverted forms of the original row distributed between two staves, as shown in Figure 3. This results in the row being played in its correct order but over two registers rather than as one linear part. Presenting the row in this way gives Palester the opportunity to create intervallic collections within each individual stave which are not present in the original row. The melodic material of each individual line is not directly related to the row and the phrases (as marked) do not move in phase with the row, but rather arch over the joins.

Each statement of the row is connected with the next by a common tone, whereby the last note of one row is the first of the next. ${ }^{32}$ Since the first and last note of the row are separated by a whole tone, the manner of connecting statements of the row creates a numerical pattern where only the even forms of the row are used. This also creates a symmetrical structure with an axis between the $\mathrm{I} 4$ and $\mathrm{P} 6$ presentations of the row. The only other piece of musical material used in this prelude is a set of two chords at the end of the second line. These hexachords utilise all twelve pitches and each represents half of the row.

Prelude II rarely states a complete tone row but instead uses a segment or part of the row. There is a vague pattern to the part of the row which is used: the first six, seven, or eight pitches from a row are played and on occasion the eleventh or twelfth pitch is added to the conclusion of the melody. Additionally, each row segment is accompanied by at least one alternative row segment, as seen in Figure 4 and Figure 5.

A large amount of the other material used in this prelude is derived from a single five-note motif based on three pitches, as shown in Figure 6. This five-note motif often acts as a textural device and is repeated in five slightly different forms. All five of these forms maintain the same rhythmic pattern, visual structure, and a similar intervallic pattern. Additionally, all of the forms of this motif contain only two interval types but are drawn from a pool of four intervals: minor second, major second, minor third, and major third.

32 Where the shared note is not obvious, in the above figure, it has been surrounded by a square. 
Figure 3. Prelude I: Tone rows. Reproduced with the kind permission of the University of Warsaw Library

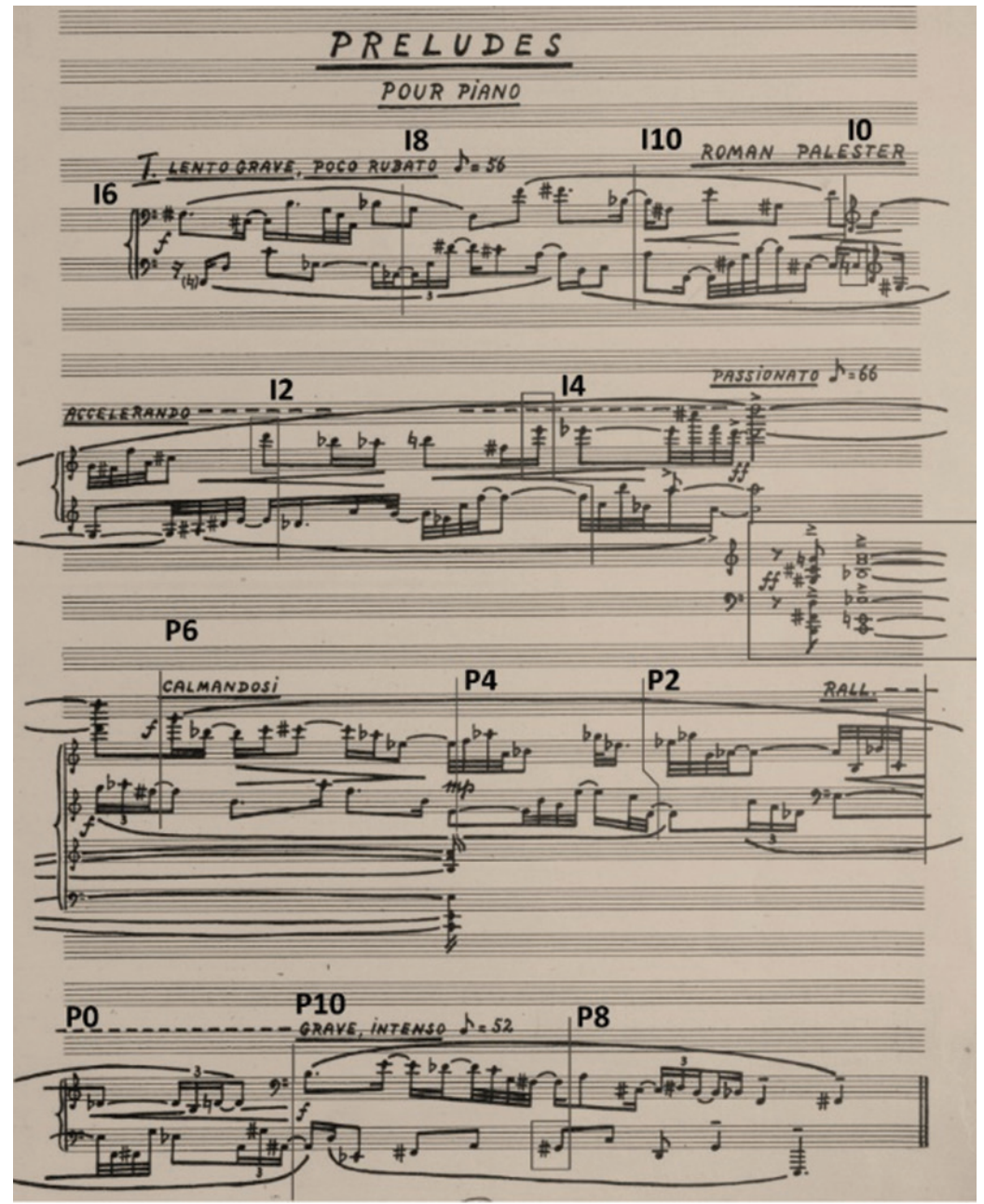


Figure 4. Prelude II: Horizontal representation of the row on the first page. Reproduced with the kind permission of the University of Warsaw Library

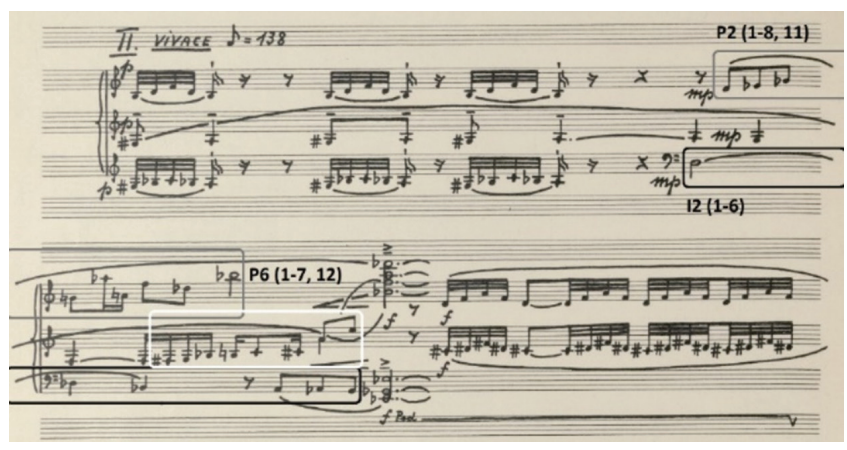

Figure 5. Prelude II: Horizontal representation of the row on the second page. Reproduced with the kind permission of the University of Warsaw Library

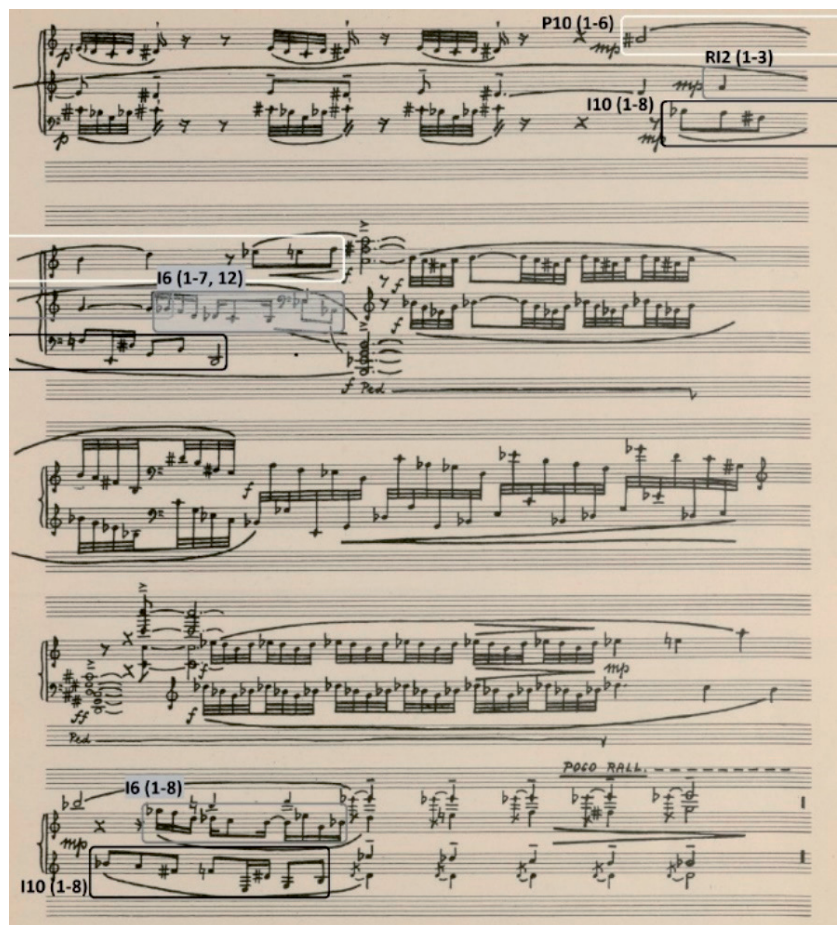


Figure 6. Prelude II: The five forms of the main motif of the first section

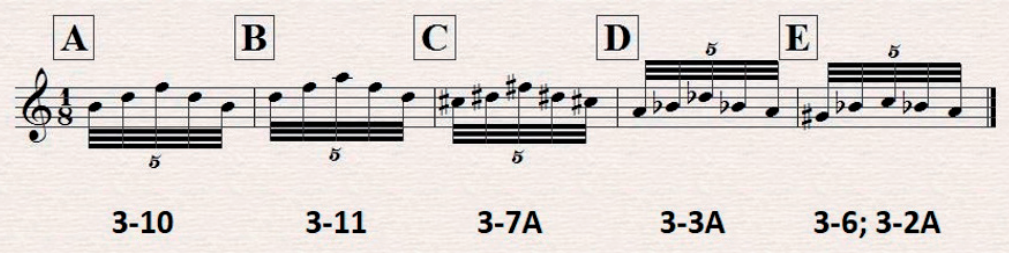

Whenever this motif appears, in any form, it is coupled with another alternative form of the motif. This can be seen in the annotated score of the first page of this prelude in Figure 7, where each motif is labelled and marked with letters A, B, C, D and E. Certain patterns appear when these motifs are combined. For instance, the $\mathrm{B}$ and $\mathrm{C}$ motifs are only presented as a pair, while the A motif is coupled with either the D or E motif. This motif could also be explained as a broken chord. Given the rapid and repeated way in which it is presented, the motif does appear to serve the purpose of a textural harmonic device. Finally, it is possible that some of these motifs were derived from the original row. The D motif for example uses the same intervallic pattern as the first three notes of the original row.

In other sections of the work a segment of the row is presented, repeated and transposed in an almost thematic fashion. A structure of this kind can be found on the third line of page 4 and is shown in Figure 8. In this case the first eight tones of the prime form of the row are presented and transposed three times by a major third, resulting in all twelve of the available pitches being played.

The same technique is employed in the repeated first section at the end of the movement. In this example, however, the right-hand and left-hand parts have been swapped and the transposition of a major third now moves in the opposite direction, as shown in Figure 9. In this case the accumulated eight-note set does not correspond directly to any of the forms of the original row, instead, it represents a development of the motif which was shown in Figure 8. 
Figure 7. Prelude II: Textural motifs. Reproduced with the kind permission of the University of Warsaw Library

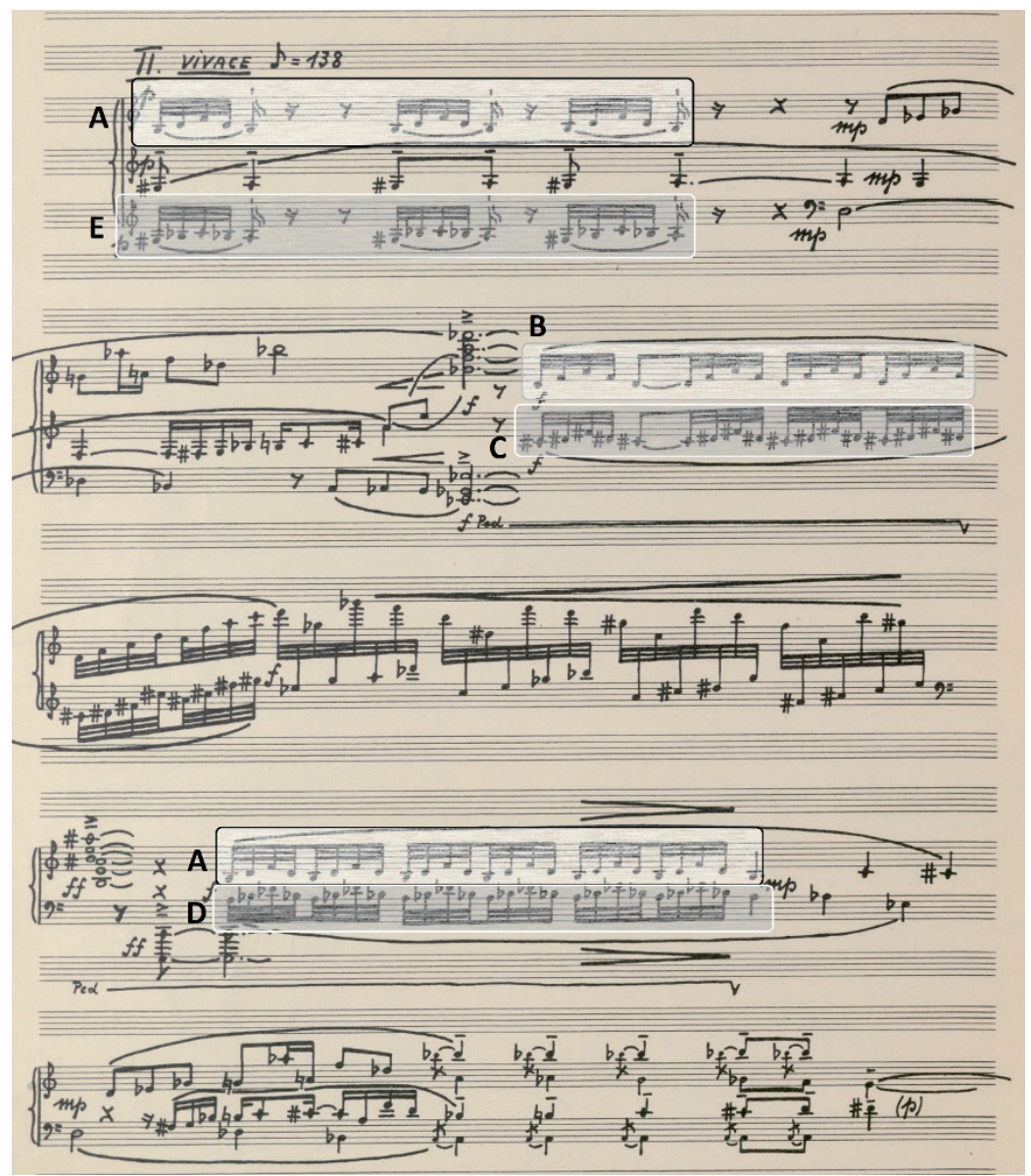

Figure 8. Prelude II: Repeated motif transposed by a major third on page 4. Reproduced with the kind permission of the University of Warsaw Library

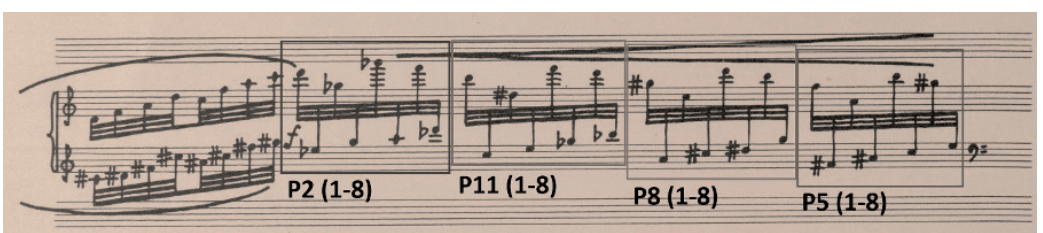


Figure 9. Prelude II: Repeated motif transposed by a major third on page 5. Reproduced with the kind permission of the University of Warsaw Library

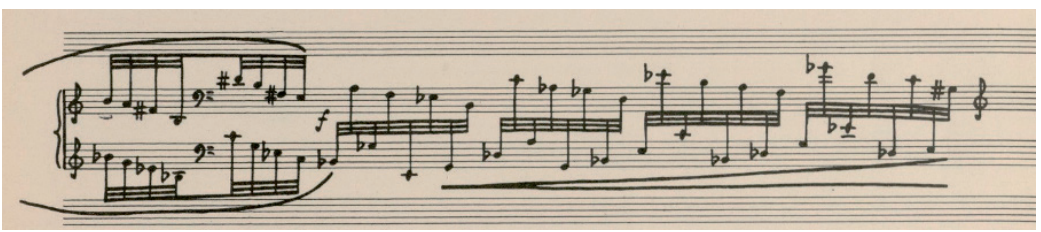

Finally, a structure is created using a pattern of chromatic transposition at the conclusion of page 4 (Figure 10) and then in a revised form on the fifth line of page 5 (Figure 11). This symmetrical structure is comprised of a set of inner voices, moving by semitones in contrary motion, reaching an axis of symmetry in the final notes of the bar - D sharp and E natural, while the upper and lower voices hold the same pitch throughout.

Figure 10. Prelude II: The first statement of a contrary motion trope cycle

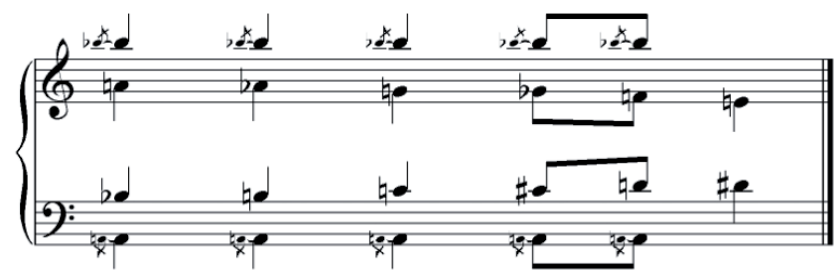

The second appearance of this structure uses the same principal, but with the inner voices moving in the opposite direction. Additionally, the intervallic pattern here is slightly different with the space of a tone being used between the first and second notes and semitones thereafter.

Figure 11. Prelude II: The second statement of a contrary motion trope cycle

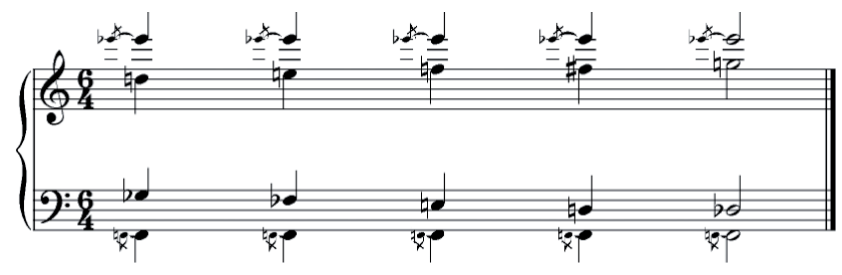


In Prelude III Palester appears to use a twelve-tone technique similar to that outlined by Josef Matthias Hauer's (1883-1959) in 1926 in his book, Zwölftontechnik. Die Lehre von den Tropen [Twelve-Tone Technique: Teachings on the Tropes]. ${ }^{33}$ Hauer's technique presents a twelve-tone row as a collection of twelve tones played together in time without a fixed order or direction, hence the label: trope. ${ }^{34}$ Similarly to a row, in a trope no one pitch can be repeated within the trope until the full twelve tones have been played. At the beginning of Prelude III Palester writes two tropes: the first trope is complete, and the second is complete but with a doubled $\mathrm{F}$ sharp. After this, the trope concept seems to disappear and the Po form of the original row is played in the bass line, as marked in Figure 12.

Following this, a segment of the Po original row is played and an eightnote chromatic movement is introduced. The final line of the prelude appears to introduce a new row which is unrelated to both the original row ${ }^{35}$ and the eight-note chromatic figure. The inclusion of this "new" row suggests that the preludes were not created entirely from one tone row. The remainder of the work's material is largely motivic in nature and has been derived from the opening tropes. The only exception is an eight-note polychord played halfway through the second line of the prelude. This polychord has instead been constructed using quintal harmony, a technique which $\mathrm{Pa}$ lester had used in some of his previous compositions.

Prelude IV opens with a melodic line in the outer parts which states a tone row derived from the Preludes' original row, using a technique of reordering which Palester also uses in La mort de Don Juan, written five years later. In his sketches for La mort de Don Juan, Palester provides several different permutations for the row, including two patterns for a linear reordering of the row. ${ }^{36}$

Josef Matthias Hauer, Zwölftontechnik. Die Lehre von Den Tropen (Wien: Universal Edition, 1926).

34 John Covach cited in Arnold Whittall, The Cambridge Introduction to Serialism (New York: Cambridge University Press, 2008).

35 Even the numerical reorderings of a row which Palester utilises in La mort de Don Juan do not connect this new row to the Preludes' original row.

36 These sketches are not readily available but were included in Zofia Helman's book on Palester and provide a snapshot into a detailed extrapolation and variation system which 
The pattern presented in these sketches and used in this prelude could be based on hexachordal permutation, since the row alternates between the two hexachords of the original row, as evidenced in Figure 13.

Figure 12. Prelude III: Tropes and tone rows. Reproduced with the kind permission of the University of Warsaw Library

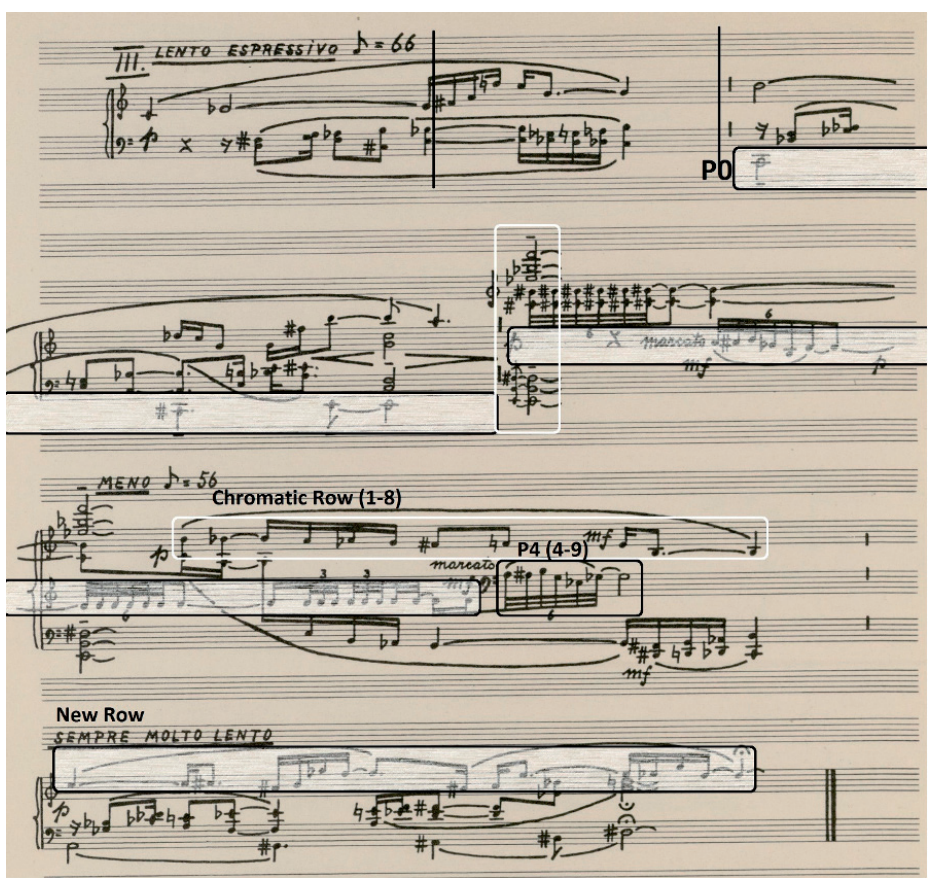

Figure 13. Prelude IV: A reordered row

\begin{tabular}{|c|c|c|c|c|c|c|c|c|c|c|c|}
\hline \multicolumn{10}{|c|}{ P2 Version of the Original Row } \\
\hline 1 & 2 & 3 & 4 & 5 & 6 & 7 & 8 & 9 & 10 & 11 & 12 \\
\hline D & E b & F\# & G & A b & A & F & C\# & E & B & B b & C \\
\hline \multicolumn{10}{|c|}{ Reordered Row used in the Prelude IV } \\
\hline 1 & 7 & 2 & 8 & 3 & 9 & 4 & 10 & 5 & 11 & 6 & 12 \\
\hline D & F & E b & C\# & F\# & E & G & B & A b & B b & A & C \\
\hline
\end{tabular}

Palester used in order to construct musical material based on a single tone row. See Helman, Roman Palester. Twórca i dzieło. 
The melodic line, discussed above, is presented in octaves in the outer parts, in uneven note values, and is paired with an inner quasi-accompanimental texture build from a set of four possible harmonic intervals: major second, minor third, major third and perfect fourth. This section has been provided in Figure 14. Palester's decision not to include the two most dissonant intervals, minor second and tritone, perhaps indicates that he was less interested in these conflicting harmonics. Finally, the quasi-accompanimental texture does not always use the same intervals. However, the purpose of this part and its construction remain similar throughout.

The second section of this prelude begins at the Poco meno tempo change with a repeated ascending six-note set played over a $\mathrm{G}$ flat drone, shown at the conclusion of Figure 14. These pitches when combined create a double harmonic scale which contains two harmonic tetrads featuring augmented seconds. The double harmonic scale also features radial symmetry with an axis around the scale's centre note, as evidenced in the annotated copy of this scale in Figure $15 \cdot{ }^{37}$

Figure 14. Prelude IV: Opening section. Reproduced with the kind permission of the University of Warsaw Library

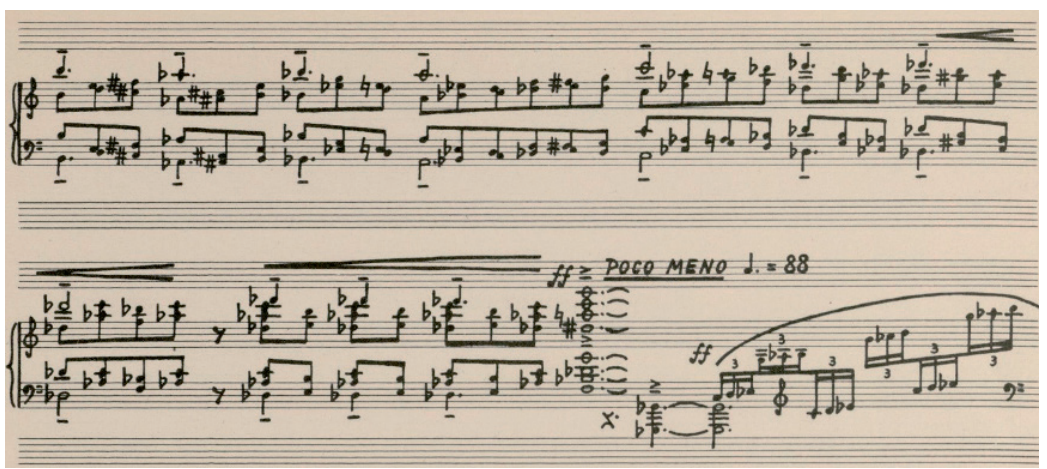

37 A double harmonic scale is also used in Prelude $\mathrm{V}$. 
Figure 15. Prelude IV: The double harmonic scale

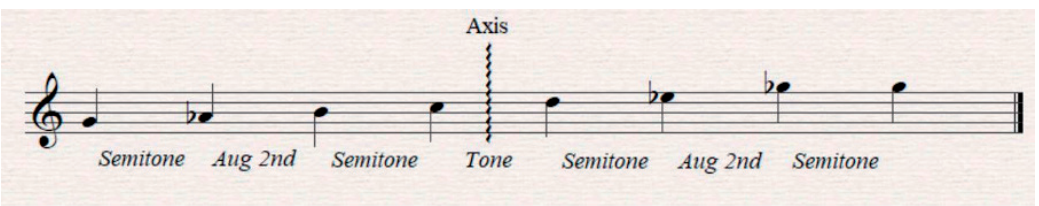

The remainder of the second section uses a similar texture to the opening of this prelude: with a melodic line in octaves in the upper parts and a quasi-accompanimental series of intervals below. The melodic line, highlighted in Figure 16, takes the reordered version of the original row used at the beginning of this prelude (Figure 13) and presents the RI2 form of this row. The adaptation of the row continues, however, with the RI2 row starting on the ninth pitch, F natural, followed by the first eleven pitches of the row $(9,1-11)$. The harmonic intervals presented underneath this row are similar to those used in the opening section of this prelude.

Figure 16. Prelude IV: Second section reordered row. Reproduced with the kind permission of the University of Warsaw Library

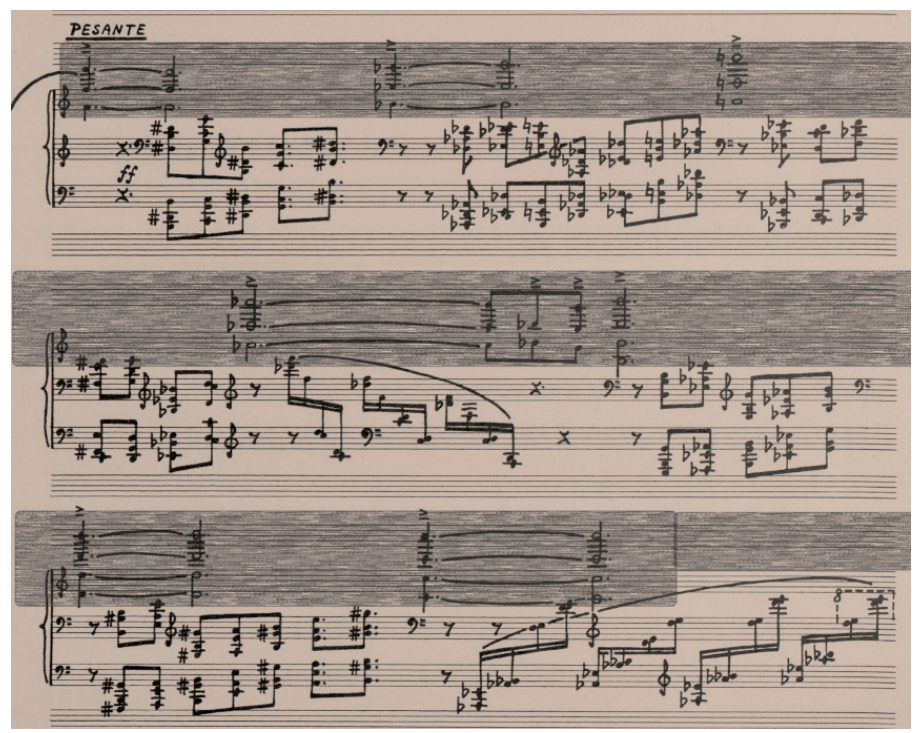


The short third section which follows is also based on a melodic texture created using the reordered row, this time in the lower voice, as highlighted in Figure 17. Above this a series of semi-quavers creates an alternative texture, an almost free-form series of phrases which gradually ascend the keyboard.

Figure 17. Prelude IV: Third section reordered row. Reproduced with the kind permission of the University of Warsaw Library

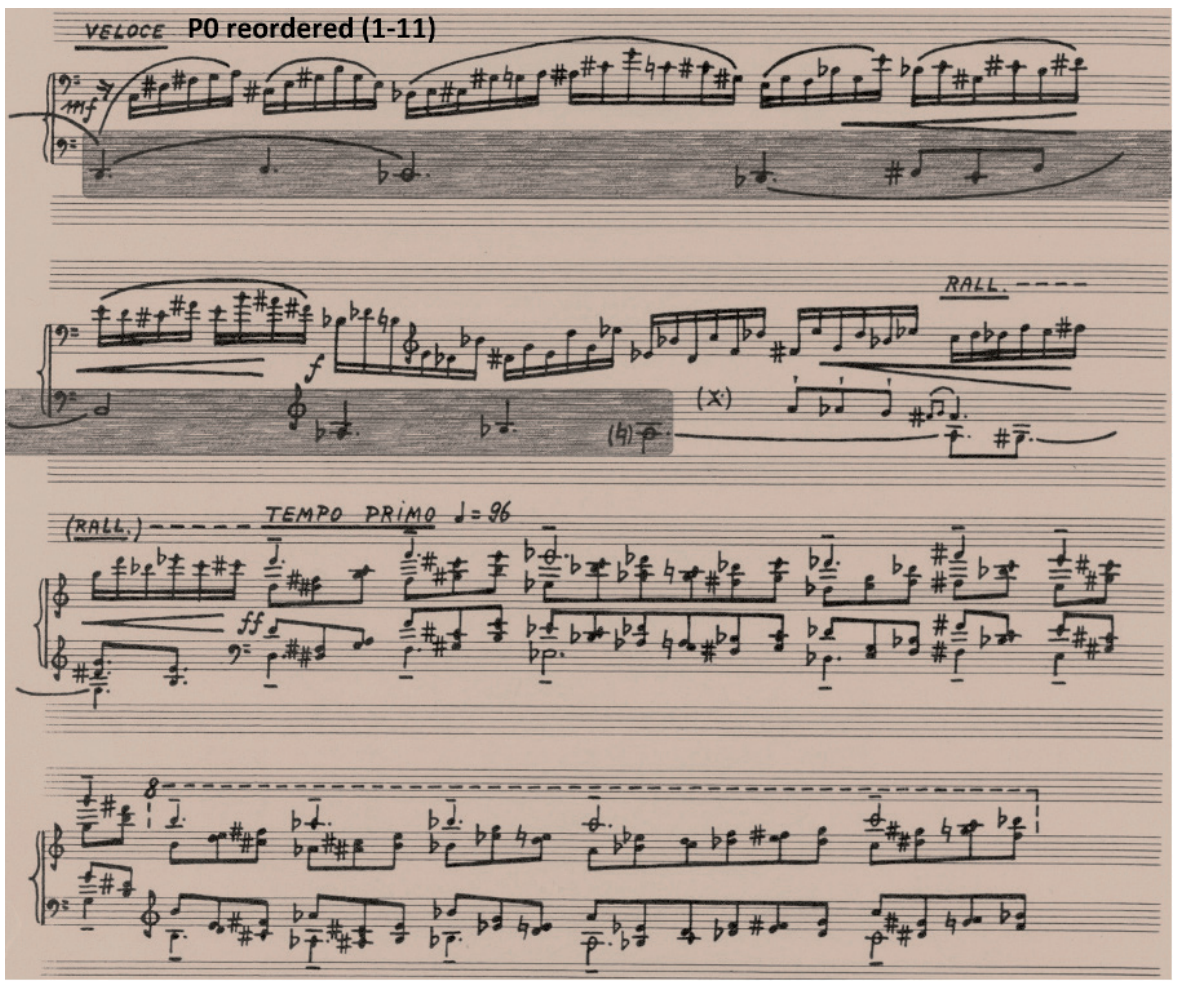

Prelude IV concludes by revisiting the material and textures presented in the opening section, using the same row and harmonic structures. This prelude shows that Palester was prepared to reorder the original row and that a desire for textural consistency often resulted in him combining the row with a series of similar harmonic collections. 
Helman, Dzierżanowski and Maculewicz noted the diatonic nature of Prelude V. ${ }^{38}$ However, Prelude v still relies on a twelve-tone row to construct the work's melodic and harmonic material, although the material created carries tonal implications. Both the opening and closing sections of this prelude are made up of two constituent parts: a set of four-note chords, followed by a two-voice motif in contrary motion by steps of a perfect fifth, as seen in Figure 19. This two-voice motif represents sections of a symmetrical tone row where each tone is separated by a perfect fifth. The upper voice uses the prime form of this row and the lower voice - the retrograde version, as shown in Figure 18.

Figure 18. Prelude V: Row of perfect fifths. The first line represents the prime form of the row, as used in the upper stave. The second line represents the retrograde form of the row, as used in the lower stave

\begin{tabular}{|l|l|l|l|l|l|l|l|l|l|l|l|l|}
\hline B b & D\# & G\# & C\# & F\# & B & E & A & D & G & C & F & B b \\
\hline B b & F & C & G & D & A & E & B & F\# & C\# & A b & E b & B b \\
\hline
\end{tabular}

The row is never presented in its full form, however, as each time this collection is played it starts from a different point in the cycle and each stave presents only five pitches. This row is used three times in the opening section with each playing linked to the next: the final notes of one playing are the first notes of the next. This results in all twelve tones sounding within each part over the course of this section. This collection is used in reverse contrary motion in the repeated first section at the end of the prelude. In Figure 19 the four-note chords which separate each presentation of the row are all of the same type, the all-interval tetrachord or 4-z29 using the Allen Forte pitch class system. ${ }^{39}$ Chords of this type are interesting as their interval vector contains one of every interval and they can be presented in both a prime and inverted form. ${ }^{40}$

38 Helman, Dzierżanowski, and Maculewicz, Roman Palester.

39 Allen Forte, The Structure of Atonal Music (New Haven: Yale University Press, 1973).

40 Whittall, The Cambridge Introduction to Serialism, 271. 
Figure 19. Prelude V: Opening section. Reproduced with the kind permission of the University of Warsaw Library

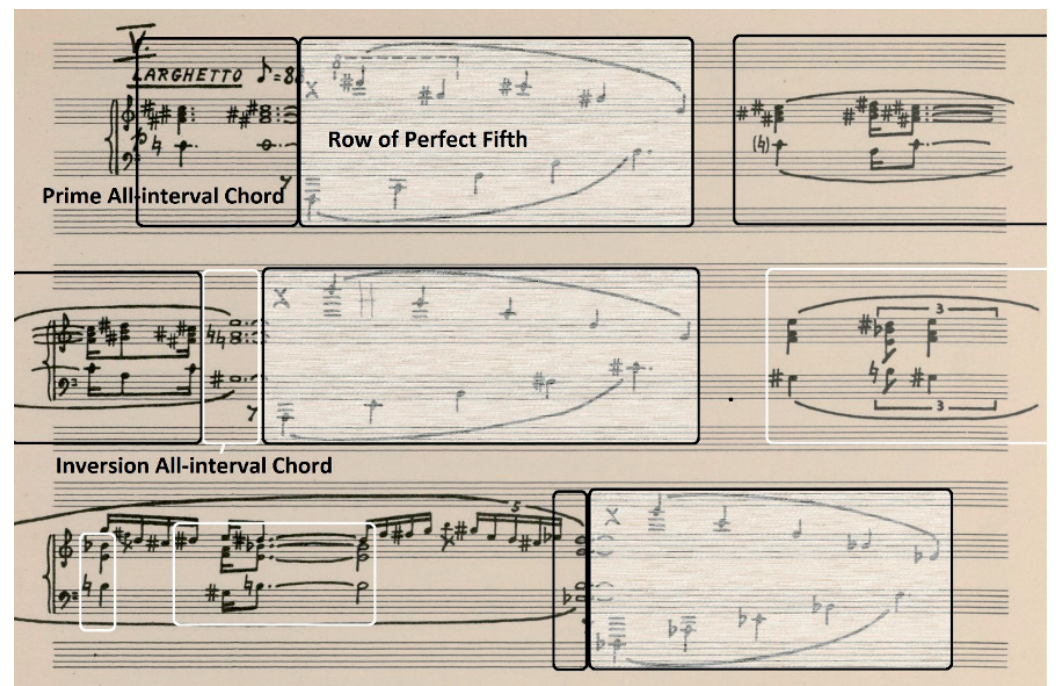

The first section of Prelude $V$ finishes with a set of triads, including 4-14, $4^{-17}, 4^{-19},{ }^{41}$ and two all-interval tetrachords, as shown in Figure 20. All of these triads recall diatonic tonality and could be explained as major or minor triads with an additional tone added, often a seventh or eleventh. Following these triads, the double harmonic scale from Prelude IV returns, presented here as a seven-note polychord.

Figure 20. Prelude V: Chords from the fourth line of page 10

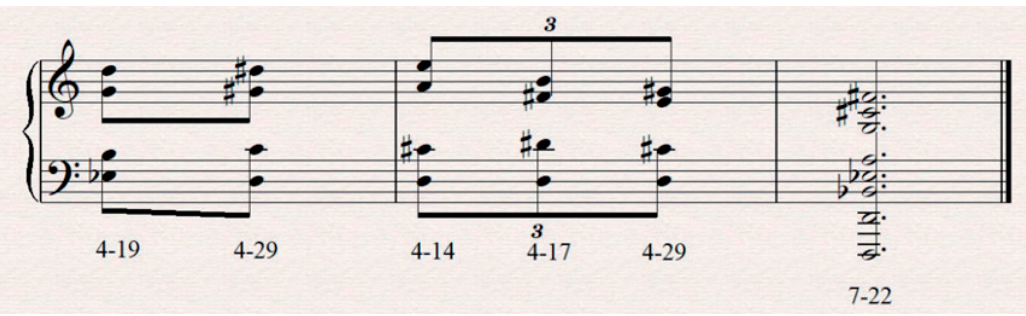

41 These are the numbers assigned to these chords by Allen Forte in Forte, The Structure of Atonal Music. 
In Prelude vi importance is placed on motivic repetition and oscillating tonality. At only one point is a trope or row used prominently, at the beginning of the second page where a trope is repeated twice, as shown in Figure 21. If the linear order of the trope presented here is examined, it does not create a row which corresponds with the original one or the reordered rows identified thus far. Moreover, the speed with which the trope is played, its upward trajectory, and its placement between two segments of the prelude all suggest that Palester intended to use this as a gestural device, not a melodic phrase. Palester had employed rapid ascending chromatic movements in order to connect sections in some of his previous works.

Figure 21. Prelude VI: A trope and a gestural device. Reproduced with the kind permission of the University of Warsaw Library

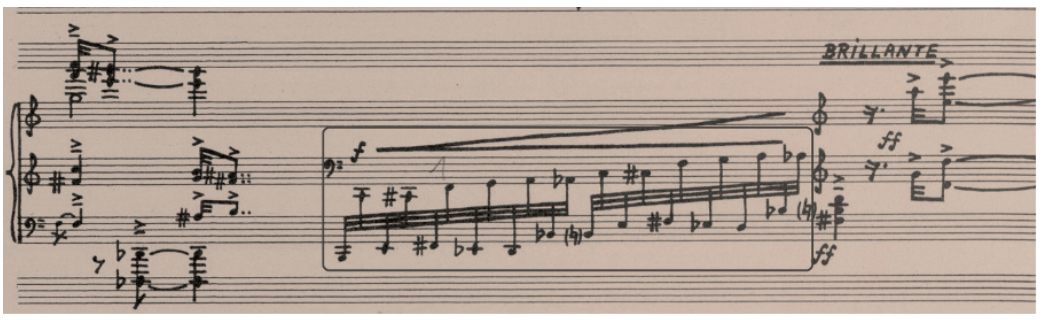

Generally speaking, Prelude VI applies twelve-tone technique in a more liberal fashion, allowing for the repetition of pitches but still striving to present all twelve tones. Take the opening line for example. Here the upper voice is built around a six-note hexachord of D, E flat, F, G flat, A flat, and B flat, as shown in Figure 22. The middle voice is based on a set of four pitches with a repeated semitone oscillation between $F$ sharp and $G$ natural.

Motivic repetition can be found frequently in this prelude. One example of this is in the final line of page 12. Here a set of three melodic motifs with similar intervallic structures and based on the same rhythmic cell are presented and repeated three times, as highlighted in Figure 23. 
Figure 22. Prelude VI: Opening line. Reproduced with the kind permission of the University of Warsaw Library

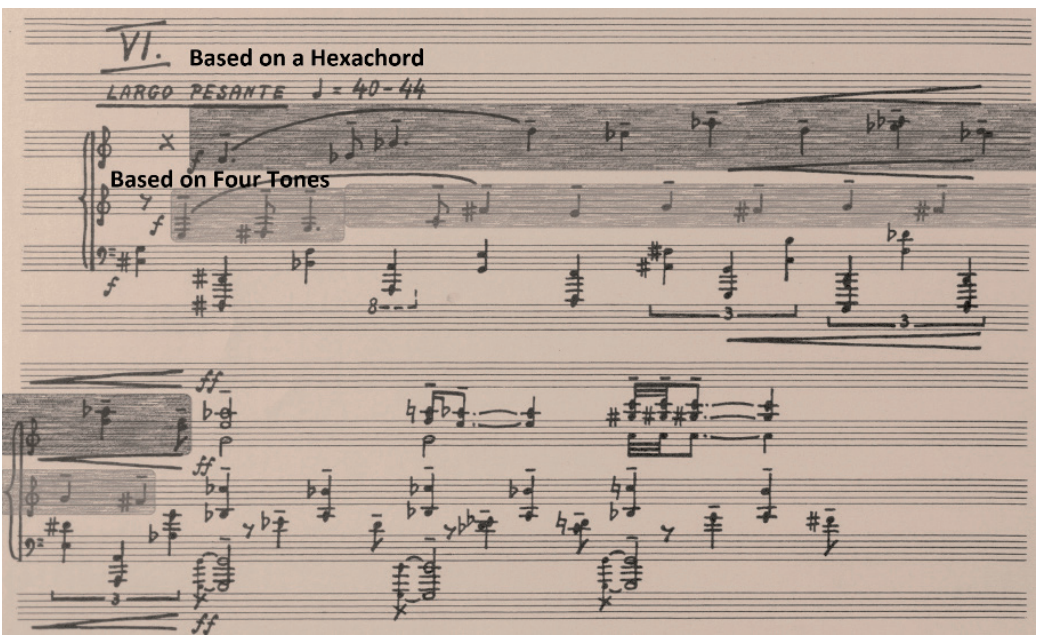

Figure 23. Prelude VI: Example of motivic repetition. Reproduced with the kind permission of the University of Warsaw Library

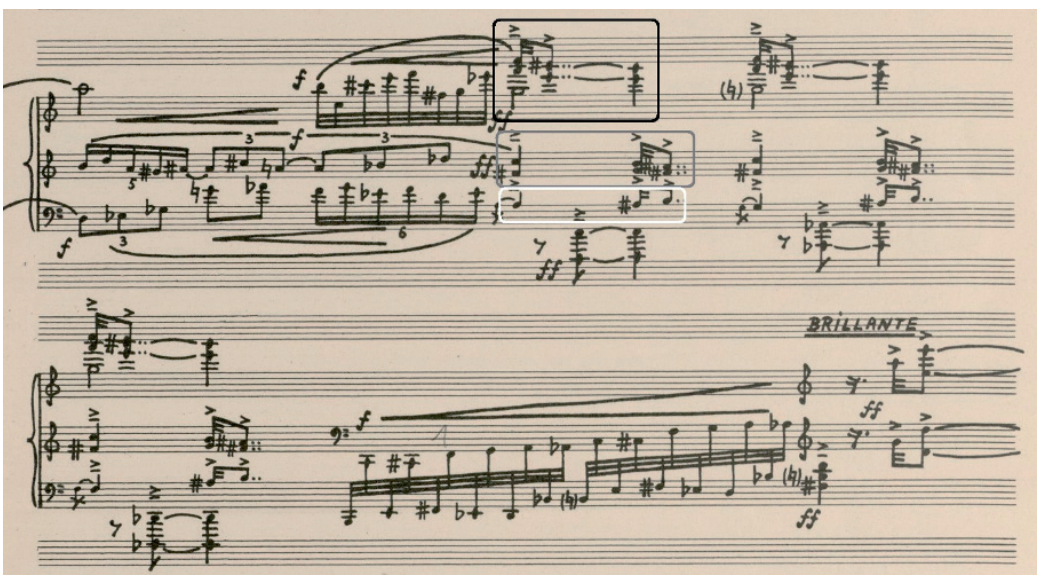

The ending of Prelude VI, from the pesante tempo marking, is also worth examining as it provides further insight into how Palester structured his pitch material. This segment consists of two textures: the inner 
voices which repeat a set of semitone movements and the outer voices which play a series of three harmonic structures in contrary motion to one another, as shown in Figure 24. A similar structure built on contrary motion movement was used in Prelude II and shown in Figures 8 and 9. In Prelude VI this structure leads to the creation of a seven-note polychord which concludes the prelude. Given the way in which the final chord is presented it may perhaps be an example of Palester's previous technique of creating polychords through triadic layering. In this case the polychord is constructed using a D minor triad in the lower part and C sharp minor seventh triad in the upper part. The resulting polychord is heavily chromatic.

Figure 24. Prelude VI: Conclusion. Reproduced with the kind permission of the University of Warsaw Library

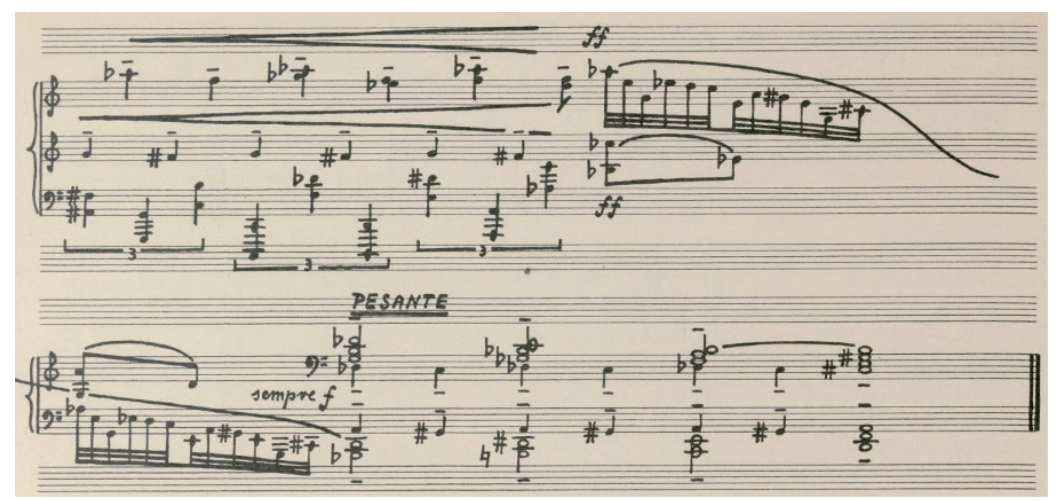

The first section of Prelude VII layers several forms of the original row on top of one another, as shown in Figure 25. These statements of the row include full statements of both prime and inverted forms, partial statements of the row and a variation based on the P2 form of the original row. Each statement uses a different set of rhythmic values, although certain rhythmic collections are frequently employed in all of the parts.

The repeated first section, found at the conclusion of the prelude, also layers a series of rows on top of one another, uses the same textural concepts as the first section, and a large amount of the same rhythmic material. 
The repeated first section, while using similar forms of the row does not, however, repeat the same material in its entirety, as shown in Figure 26.

Figure 25. Prelude VII: Tone rows in the opening of the prelude. Reproduced with the kind permission of the University of Warsaw Library

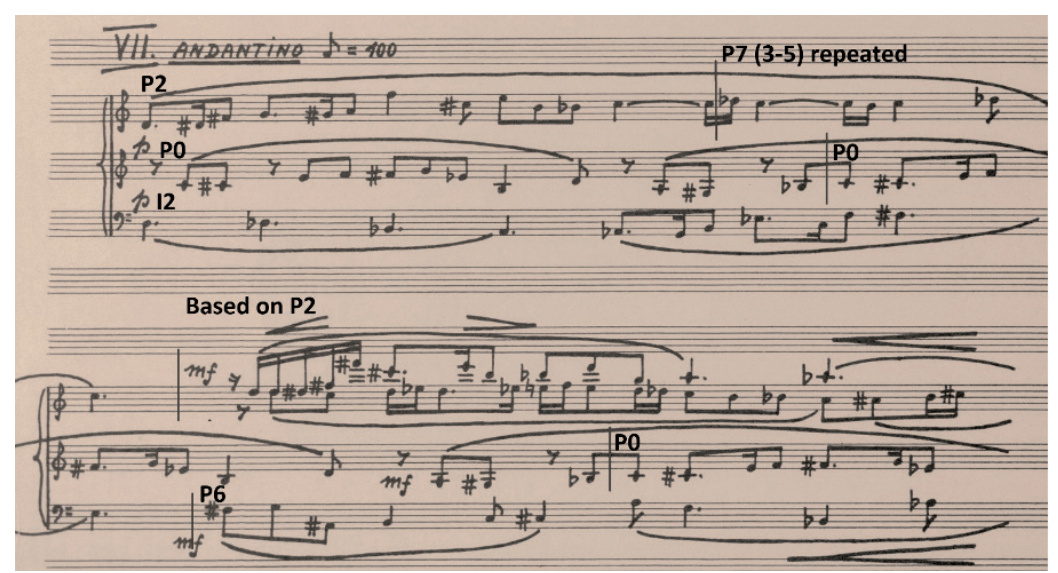

The brief middle section of this prelude features a series of $3^{-5}$ chords, also known as Viennese trichords, which contains both a perfect fourth and a tritone within the one triad. These are marked in Figure 26. The use of these triads highlights Palester's continued interest in diatonically conflicting scale degrees. Previously Palester had achieved this through the layering of conflicting triads to form large polychords, sometimes even including conflicting modality, creating what is often referred to as a major-minor chord. ${ }^{42}$

Prelude VIII highlights chromatic movement: take the opening two lines as an example: the upper voice relies almost entirely on chromatic movement, spelling out a chromatic hexachord of E, F, G flat, G, A flat and A, as shown in Figure 27. The lowest part also relies on chromatic movement, creating a chromatic tone row. The middle parts, presented toral thesis. See Parham, “The Invisible Man.” 
in rhythmic unison, employ less chromatic figures and instead rely on motivic repetition and development.

Figure 26. Prelude VII: Tone rows on the second page. Reproduced with the kind permission of the University of Warsaw Library

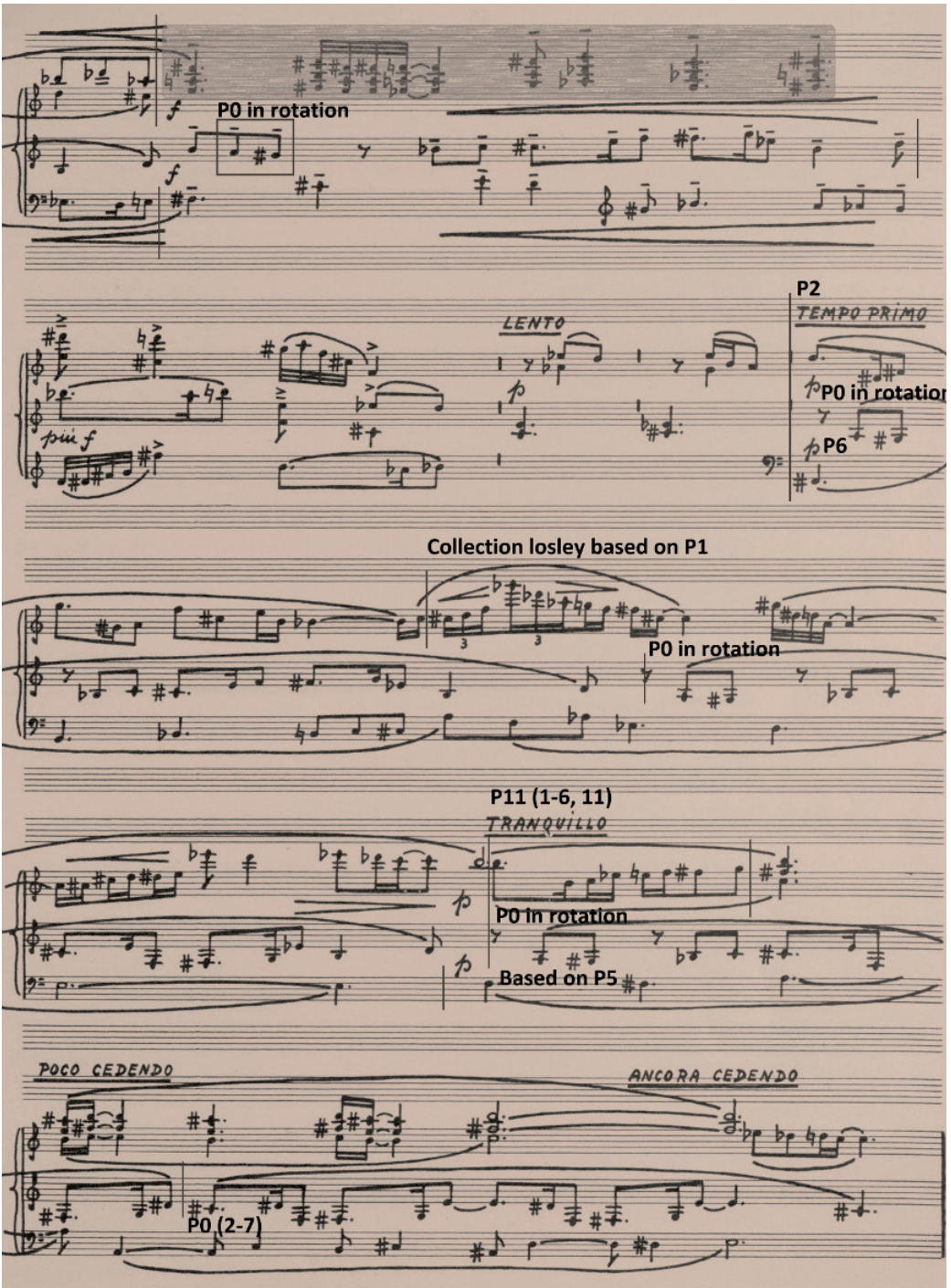


Figure 27. Prelude VIII: Chromatic collections. Reproduced with the kind permission of the University of Warsaw Library

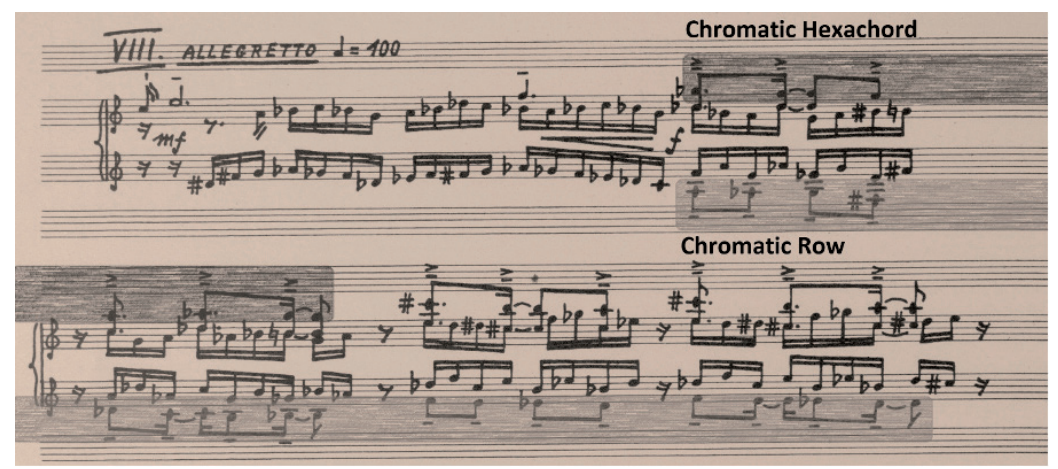

This prelude also features a number of rhythmic and textural motifs. At the beginning of page 17 (Figure 28), for example, a four-voice motif is presented which uses the same rhythmic cells and texture as the opening of this prelude (Figure 27). Here the figure is presented in full and then divided into smaller sections, labelled in Figure 28 as partial motifs.

Figure 28. Prelude VIII: Revised first section. Reproduced with the kind permission of the University of Warsaw Library

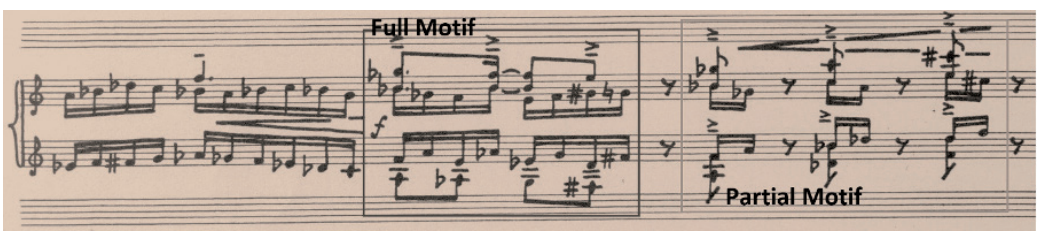

The fleeting middle section of this prelude employs the trope technique through the repetition of a series of motifs, as shown in Figure 29. This section is comprised of a repeated figure of large intervals in the upper parts and a rapidly ascending bass line. The full trope is presented twice before the intervallic and rhythmic material of the upper parts is used and developed with relative freedom for the remainder of the section.

The final section of Prelude VIII uses a slightly altered version of the material found in the opening section. This material produces a notable 
six-note motif comprised of a bass line and one of the middle voices, what is presented in Figure 30. This motif is underpinned by the harmonic relationship of a perfect fourth and is repeated fourteen times. Given the intervallic structure of the middle voice, one could presume that it was derived from the first three tones of the original row, suggesting that the basis of Palester's motivic work often still came from a row. Above this motif the upper voice presents a row based on intervals of a perfect fifth, similar to the one used in Prelude $V$.

Prelude IX presents two seemingly new tone rows, regularly features the Viennese trichord, and employs a number of repeated chromatic figures. The first new row labelled here as "Row A," is played initially by the upper voice in the opening line of the prelude, as marked in Figure 31.

This row acts as the basis for most of the work's melodic material, although the full row is rarely presented. Instead, several smaller cells are drawn from it. An example of this can be found in the final section of Prelude IX, shown in Figure 32. In this section one full presentation of the I4 form of Row A is given, however, the majority of the material used are partial statements of Row A. This section also appears to introduce a second new row, labelled here as "Row B".

Figure 29. Prelude VIII: Middle section tropes. Reproduced with the kind permission of the University of Warsaw Library
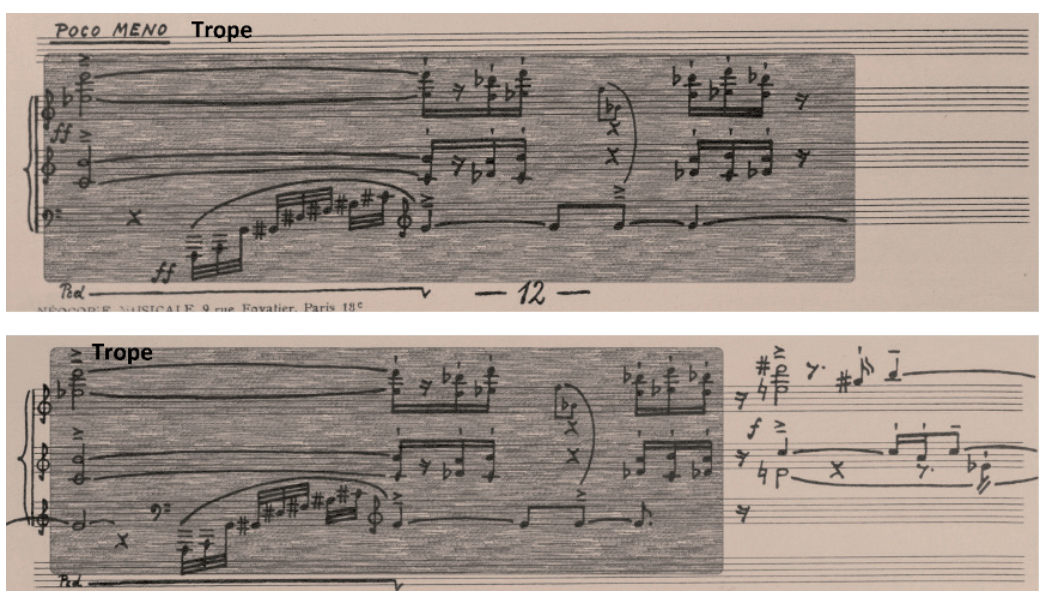
Figure 30. Prelude VIII: Final page. Reproduced with the kind permission of the University of Warsaw Library

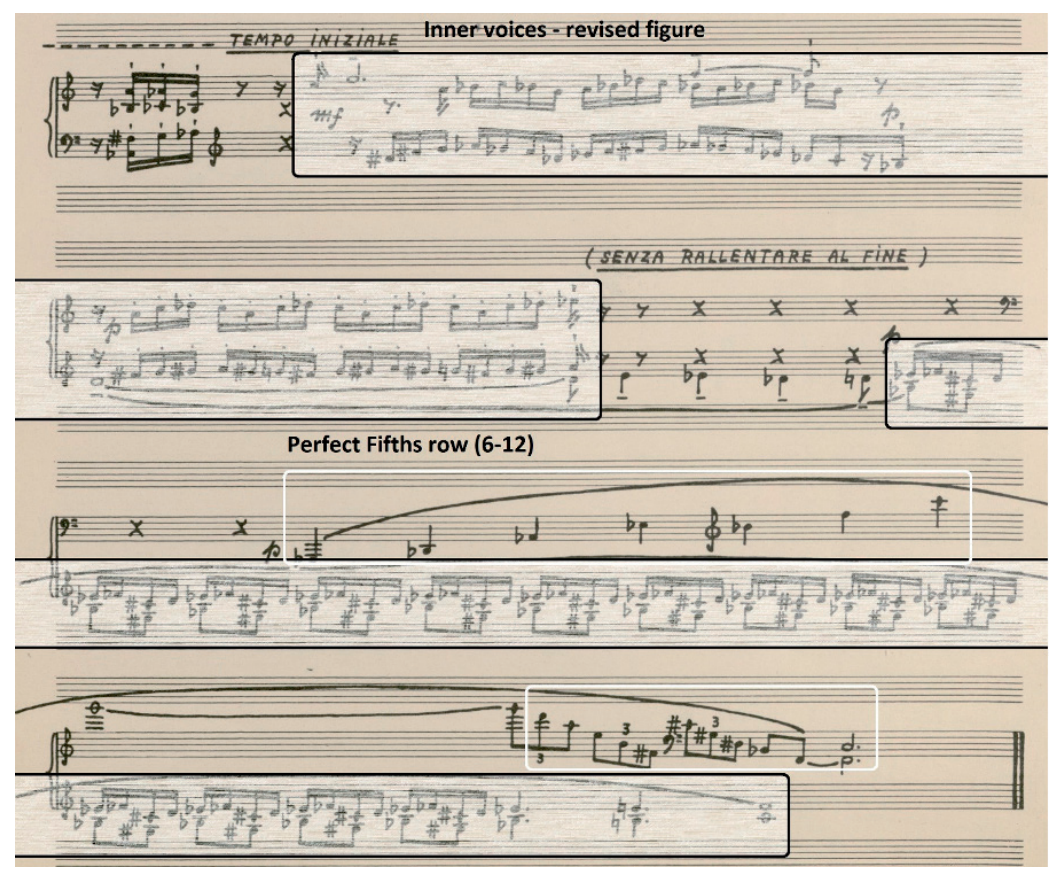

Figure 31. Prelude IX: Row A in the opening line. Reproduced with the kind permission of the University of Warsaw Library

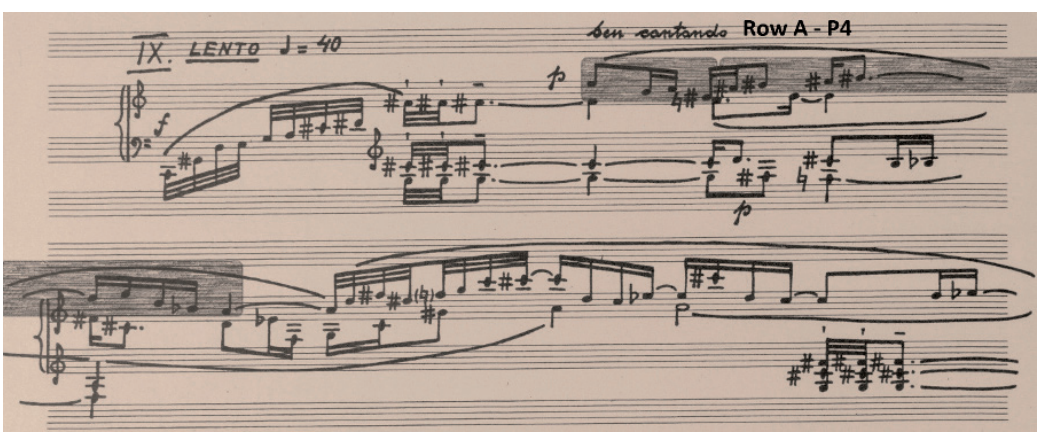


Figure 32. Prelude IX: A combination of row A and row B. Reproduced with the kind permission of the University of Warsaw Library

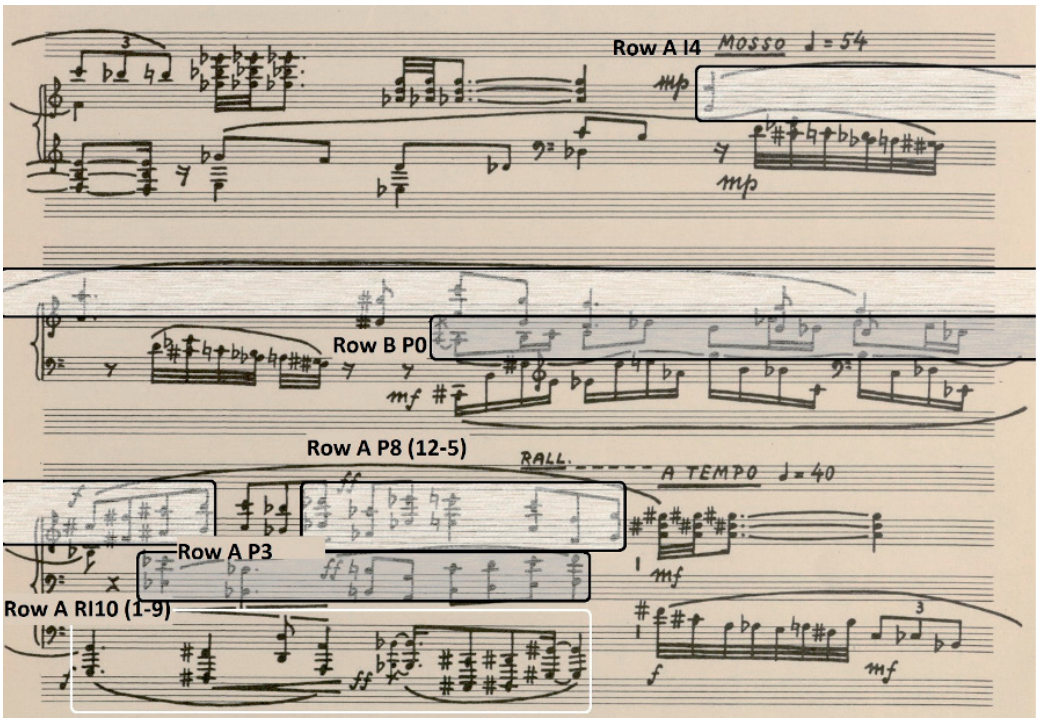

The Viennese trichord features prominently in this prelude, always played with the same rhythmic pattern of two demisemiquavers followed by a longer rhythmic value, usually a minim or more in length. The repeated use of a Viennese trichord motif has been highlighted in Figure 33. In this context the Viennese trichord becomes a punctuating or accompanying motif, appearing fourteen times, and is featured at both the beginning and end of the prelude.

Finally, a large amount of the material used in this prelude employs chromatic movement. Take the first line of the Molto cantabile section on page 20 as an example (Figure 34) where the inner voices oscillate between two different semitones (comparable to the passage heard at the close of Prelude VI). At the same time, the upper voice presents a descending fivenote chromatic figure and one of the other inner voices holds an A natural before presenting a different chromatic figure, both are marked below. 
Figure 33. Prelude IX: Viennese trichords. Reproduced with the kind permission of the University of Warsaw Library

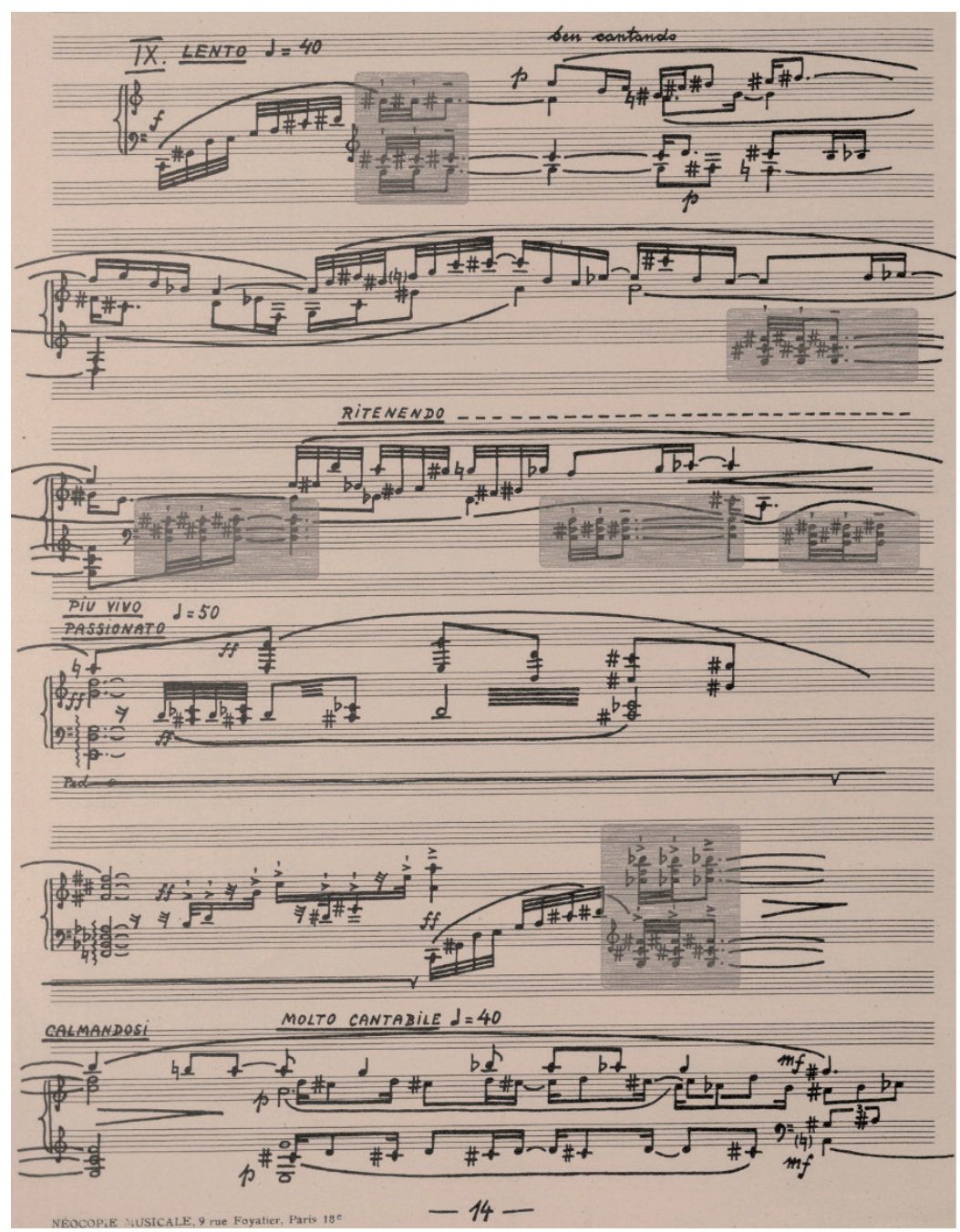




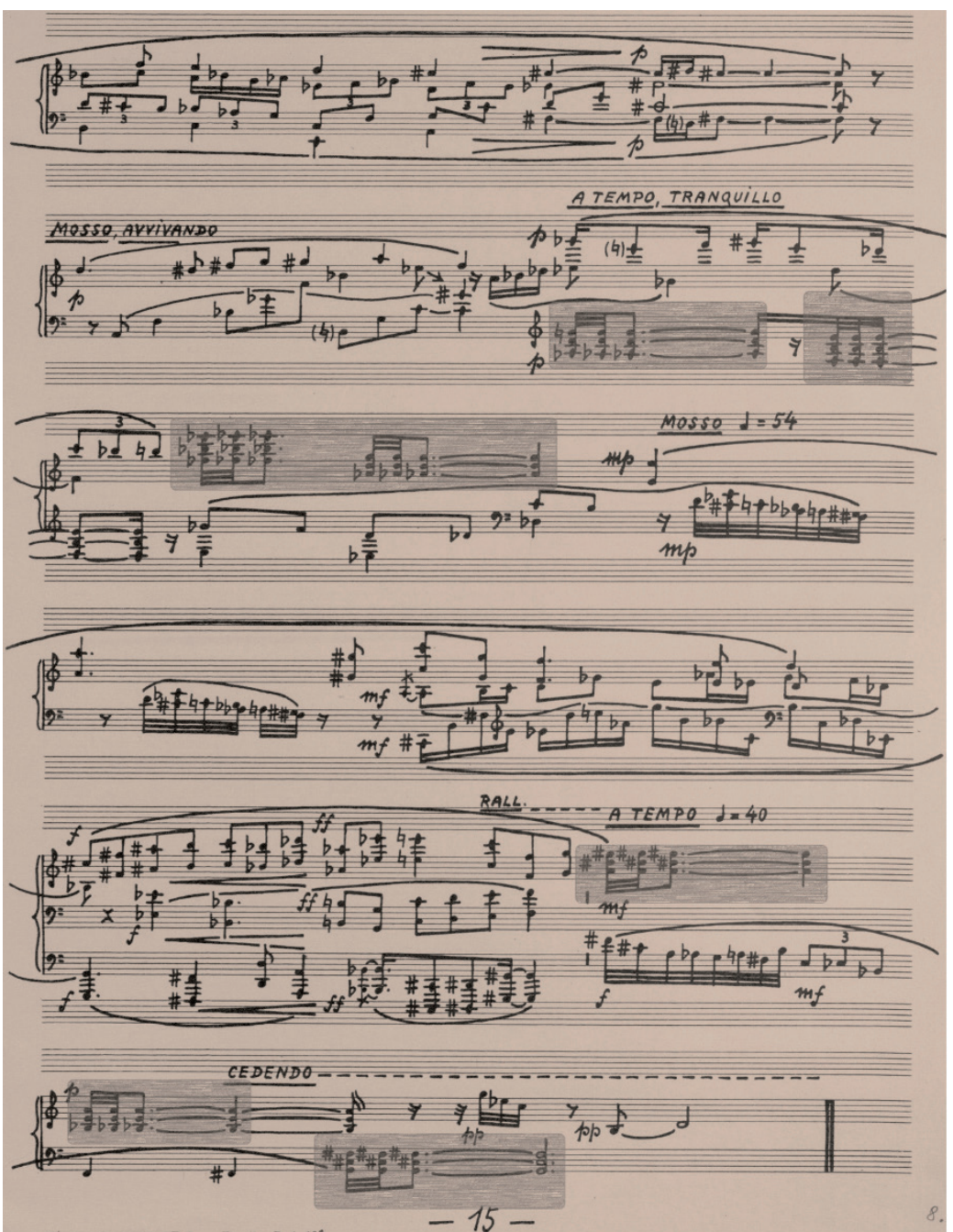


Figure 34. Prelude IX: Chromatic figures. Reproduced with the kind permission of the University of Warsaw Library

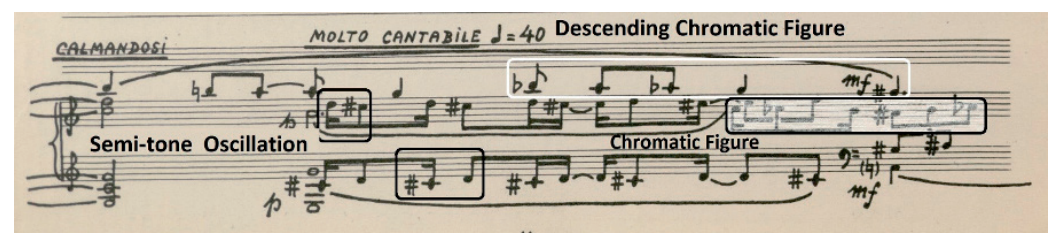

Another noteworthy chromatic figure appears initially in the final line of page 19, as shown in Figure 35. Here a solitary pitch is played followed by two more pitches, one a semitone higher and the other a semitone lower. This motif may have been derived from the P8 form of the original row, using the fourth, fifth and sixth pitches.

Figure 35. Prelude IX: Chromatic motif. Reproduced with the kind permission of the University of Warsaw Library

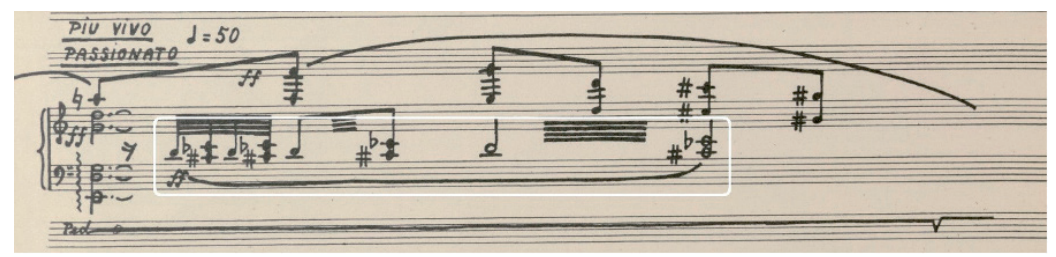

A modified version of this chromatic figure is used at the beginning of the mosso section on page 21, as shown in Figure 36. Furthermore, this motif is used not only in Prelude IX but much more extensively in the final prelude.

The opening section of the final prelude, and subsequently the section's return on page 25 , are based on the statement of a trope. Here the trope is separated into two different textures: a sustained $\mathrm{F}$ sharp in both the bass and treble parts, combined with a set of two harmonic structures ${ }^{43}$ in the middle voices to present a twelve-tone aggregate, as shown in Figure 37. This trope is repeated eight times, with only very slight rhythmic variation.

43 Using the Forte pitch class system these structures would be labelled 5-15 and 6-7. 
Figure 36. Prelude IX: Developed chromatic motif. Reproduced with the kind permission of the University of Warsaw Library

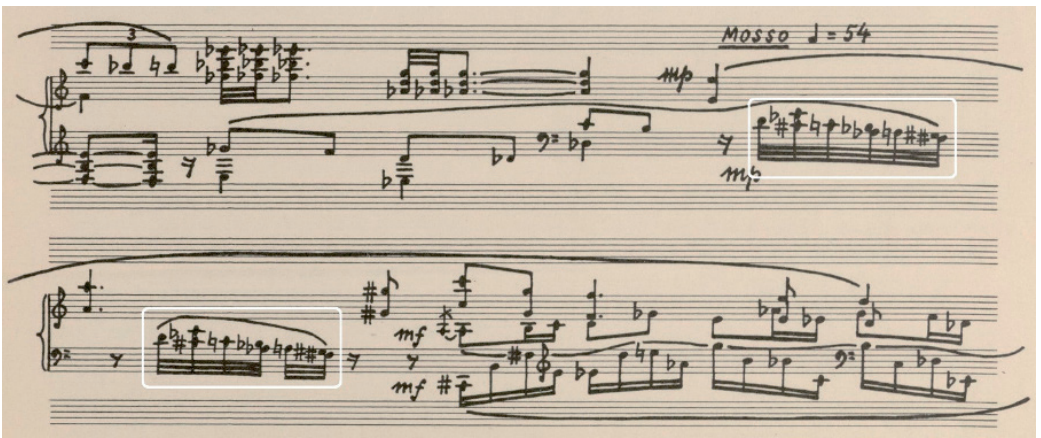

Figure 37. Prelude $X$ : Opening section tropes. Reproduced with the kind permission of the University of Warsaw Library

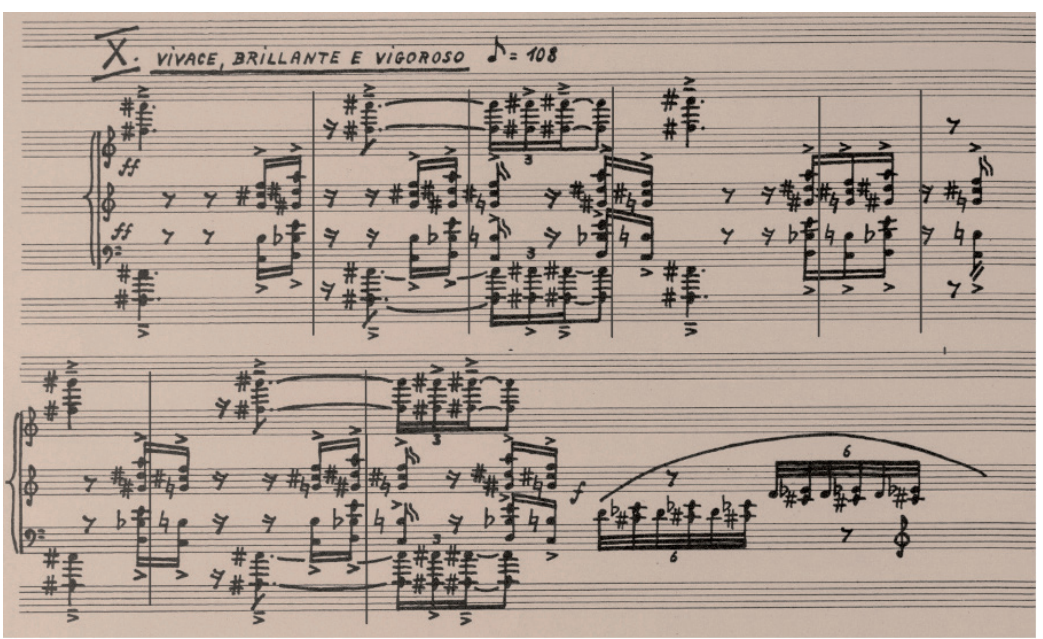

The extended в segment of the first section which follows the trope is built primarily on the repetition and development of the oscillating semitone motif introduced in Prelude IX. The use of this motif in both preludes shows that Palester's motivic ideas were not limited to individual preludes. It is played here in its original transposition and repeated thirty times before being transposed up a minor sixth, as shown in Figure 38. Underneath 
the repetition of this motif the $\mathrm{I} 6$ form of the original row is presented, although with the twelfth pitch out of order.

Figure 38. Prelude X: B segment. Reproduced with the kind permission of the University of Warsaw Library

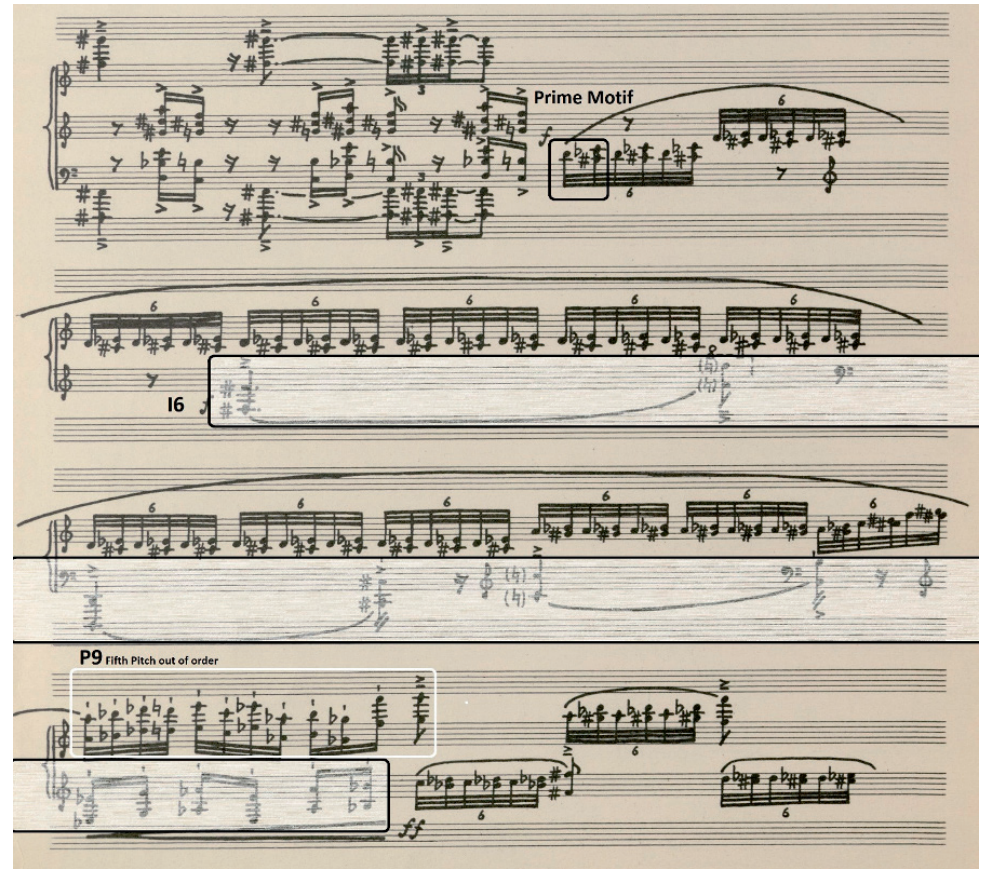

At the end of the third line of Figure 38 the motif undergoes some minor alteration allowing it to rise and fall. This is achieved by altering the position of the major second in relation to the single pitch played before it. These variants may have been generated using idiomatic keyboard patterns with the two-note groups on the black keys and the single pitches on the white keys. This motif is then presented in its descending, ascending, and prime form throughout pages 23, 24 and the first half of page 25, as shown in Figure 39. The altered motif is accompanied initially by a slightly altered version of the original P9 row and subsequently with a series of pitches loosely derived from the original row and presented over octaves. 
This extended B segment, shown in Figure 39, includes some recognisable twelve-tone sets: firstly, a reordered version of the original I6 row where the seventh and eighth, as well as eleventh and twelfth pitches have switched positions. Secondly, a trope is presented in order to provide space for the aforementioned motif to switch directions. Thirdly, a row which does not have a direct link to the original row is presented twice during this section.

Following the extended B segment, the A segment presentation of tropes is repeated to conclude the first section of the prelude. The short second section begins at the andante tempo change, at the bottom of page 25 with a four-note chromatic cluster, seen in both Figure 39 and Figure 40. This chromatic cluster is quickly replaced by a melodic line based on the Po form of the original row. In this section Palester highlights the conflicting scale degrees of a $\mathrm{C}$ natural and a C sharp, with a C sharp constantly sounded by the bass line and repeated $\mathrm{c}$ naturals found in the other voices.

Figure 39. Prelude X: B segment part 2. Reproduced with the kind permission of the University of Warsaw Library

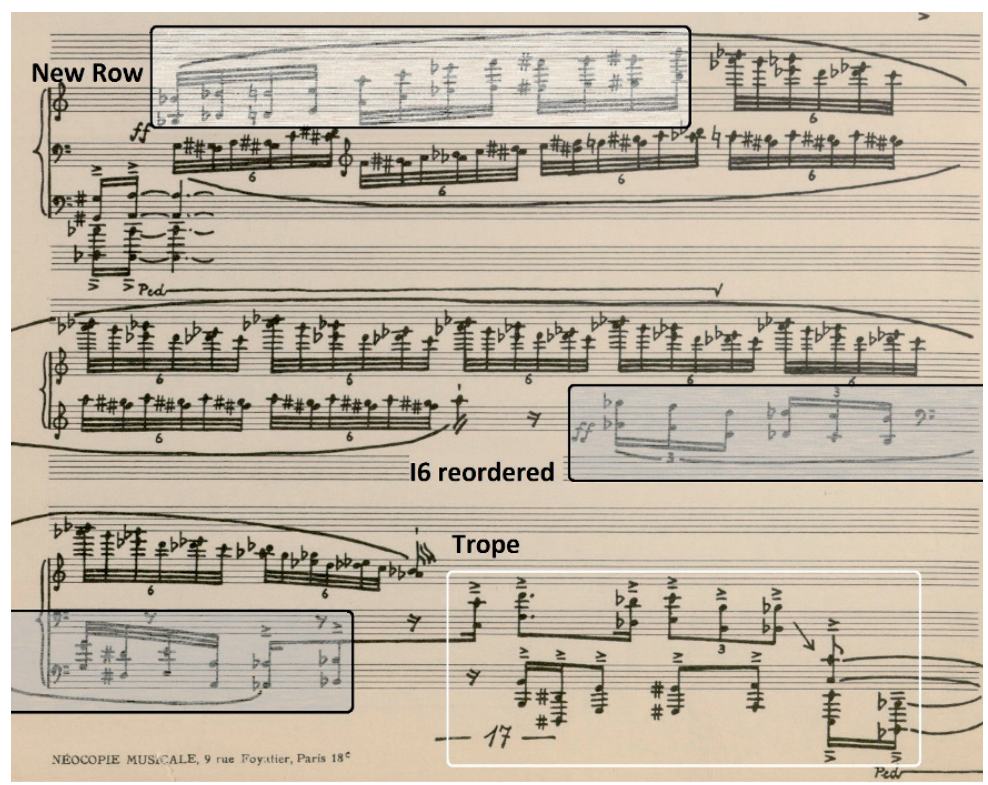




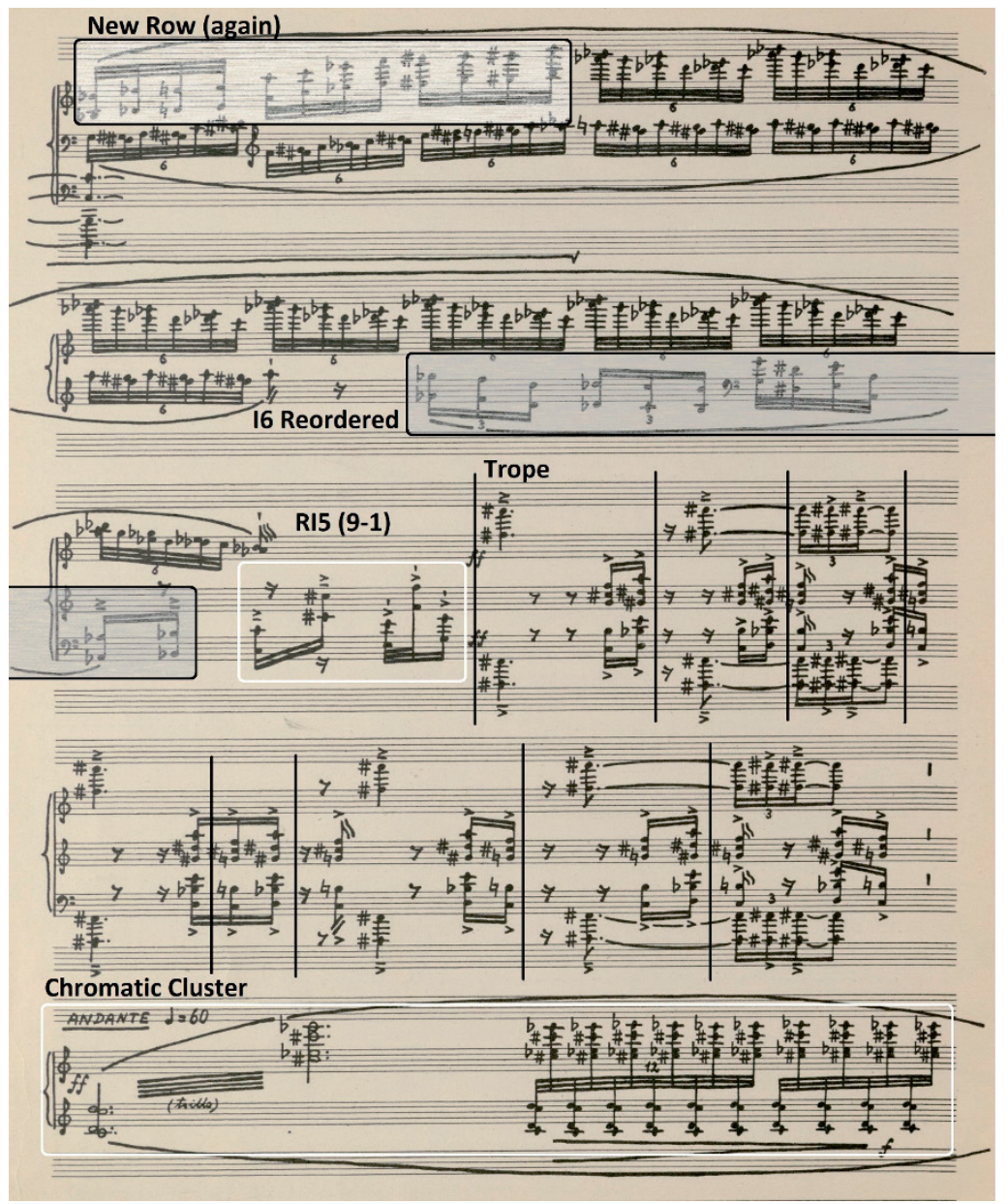

The prelude and the work conclude with a short chordal section beginning with a unison $\mathrm{F}$ sharp across four octaves, as shown in Figure 41. This is followed by a return of the trope which began Prelude $x$, stated using the same harmonic structures. The final section suggests that Palester wished to use twelve-tone techniques but in the context of emphasising some pitches over others, the prominence being given to the F sharp. Indeed, Prelude I and Prelude $X$ both begin and end with an F sharp, hence one could argue that the set of Preludes were framed with F sharp as a tonal focus. 
Figure 40. Prelude X: Second section. Reproduced with the kind permission of the University of Warsaw Library

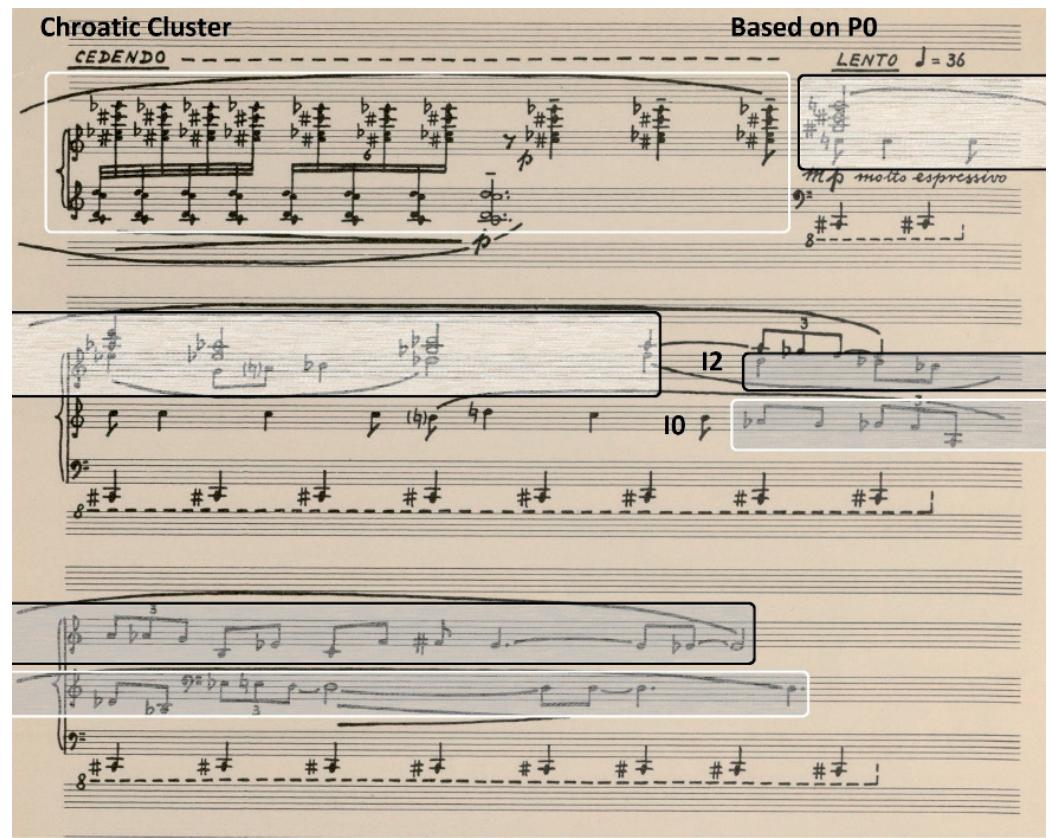

Figure 41. Prelude X: Final line. Reproduced with the kind permission of the University of Warsaw Library

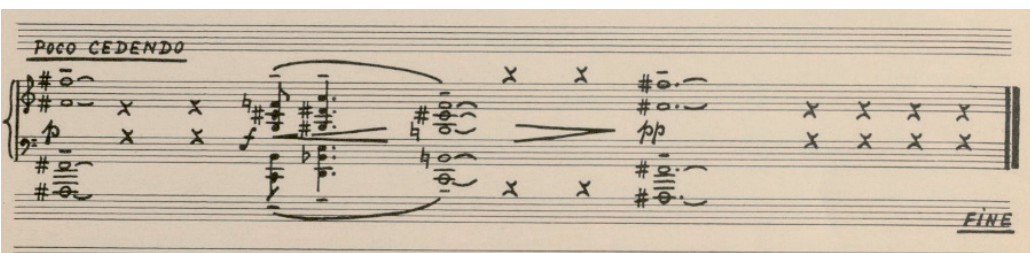

\section{Style and Musical Language - A Summary}

The main change to Palester's compositional voice in the early 1950 os was the full application of various twelve-tone techniques, as is evidenced by this discussion of his Preludes for Piano. These Preludes utilise tone rows 
as a means of generating and unifying musical material, and twelve-tone aggregates which at times have no relation to the original row. Moreover, the work does not rely only on a single row, but instead utilises a primary row, significantly reorders this row, and introduces other rows of varying types and patterns.

There are a series of structural components, symmetrical ideas, musical figures, repeated chord types, and prevalent intervals which Palester employs across these Preludes in order to develop the material produced by the tone row. This is a mark of the personalised approach Palester took, using a suite of techniques suited to his own needs rather than dogmatically following the system articulated by the Second Viennese School. In fact, Thomas Nichols made a similar observation about the work, noting Arnold Schönberg, Béla Bartók and Franz Liszt as possible influences but, ultimately, coming to the conclusion that the style of this work was distinctly individual. ${ }^{44}$ Palester's willingness to sacrifice or adjust a tone row in order to provide the melodic lines with more shape makes the Preludes, in Nichols words, "warm, intense, melodic, highly contrapuntal, generally with two or more equally distributed lines that soar to climaxes of dramatic, massive sonority." 45

The work is rhythmically dense for the most part, with layering of horizontal parts and rhythms to create tension or push the work forward. The work also makes prodigious use of the piano as a percussive and virtuosic instrument. Palester has made use of "a-metricality," writing without bar lines. ${ }^{46} \mathrm{He}$ also suggests increased freedom in tempo, often including a rubato marking. This composition utilises a number of notable chord structures and the layering of simple triads to form large polychords,

Thomas Nichols, "Preludes for Piano by Roman Palester; Sei Studi Per Pianoforte by Theo Bruins," Notes. The Quarterly Journal of the Music Library Association 21 No. 3 (Summer 1964), 457-458.

45 Ibidem, 457.

46 This is the term used by Zofia Helman when briefly discussing the work in Zofia Helman, "Roman Palester Muzyka kameralna i fortepianowa." Trans. Mackenzie Pierce, booklet essay in CD Roman Palester. Muzyka kameralna i fortepianowa / Chamber and Piano Music, performed by Jakub Tchorzewski (piano) and Duo Viennese (Warner Music 2016). 
which was a hallmark of Palester's wartime compositions, are now derived from the twelve-tone sets rather than other chord types.

These factors suggest that Palester developed some more avant-garde tendencies once he had left Poland, however, his compositional voice did not change dramatically, nor did he ignore his previous compositional techniques. The Preludes for Piano feature a number of techniques which Palester had used in his previous works, including triadic layering, motivic development, rhythmic cell repetition, and prevalent tonal conflicts. Moreover, the work's structure as a whole is fairly conservative and almost all of the preludes feature a repeated first section.

Ultimately, Palester's Preludes for Piano is a significant work in the composer's output as the cycle shows a distinct shift towards a more comprehensive use of twelve-tone techniques. This evolution in his compositional language is substantial because Palester uses techniques which would not have been considered acceptable in Poland at that time. This work in no way adheres to the regime's accepted form of composition, socialist realism. ${ }^{47}$ The question then arises how connected was this development in Palester's compositional voice with his reaction to the cultural policies of the Polish communist regime and his defection to the West? Given his involvement in Cold War politics, his strong anti-communist statements, and his work for Radio Free Europe (RFE), it is unlikely that he would not, at least, have considered the political ramifications of composing music in a style which was unacceptable to the regime in his homeland. Nevertheless, Palester had taken steps towards more dodecaphonic music prior to his defection, experimenting with elements of twelve-tone technique in Symphony No. 3 (1948-1949). ${ }^{48}$ Additionally, he had made it clear upon his defection that he would not be influenced by thoughts of political

A clear definition of the Communist Party's musical doctrine of socialist realism probably does not exist. Many have argued that this term was often keep deliberately vague as it better served the purposes of the Party. Retrospectively one might describe socialist realism as works within the light of the Marxist criteria which have a positive and uncritical attitude towards socialism. Generally, this was to be achieved by using conservative diatonic, and tonal musical language that could be understood by everyone.

48 Symphony No. 3 is discussed in detail in the author's doctoral thesis. 
allegiance or be corralled into using any particular compositional techniques based on the wishes of others. Palester was firm and unwavering in his desire to create music which he believed was of a high quality, regardless of the wants of others. His defection may have made the creation of these works easier as he was no longer hampered by the controls of the communist regime. Nevertheless, this defection did not cause stylistic evolution.

\section{BIBLIOGRAPHY/BIBLIOGRAFIA}

“Review of Belgian Radio Orchestra Concert." Pourquoi-Pas (21 October 1949).

“Roman Palester." Muzyka (May 1947).

"Roman Palester." Lidové Noviny (2 June 1948).

Krzysztof Bilica, "Palester Roman.” In Polish Music. Polish Composers 1918-2010. Edited by Marek Podhajski. Gdańsk: Akademia Muzyczna im. Stanisława Moniuszki, and Katolicki Uniwersytet Lubelski Jana Pawła II, 2013.

Mikołaj Blajda, “Roman Palester - Requiem Analiza i interpretacja dzieła”. Kraków: Akademia Muzyczna w Krakowie, 2000.

Nadia Boulanger, “Roman Palester.” Spectateur (17 December 1946).

Grzegorz Fitelberg to Roman Palester. Letter Collection from 1945 to 1950 . University of Warsaw Library: Polish Composers Archives, Palester Collection.

Allen Forte, The Structure of Atonal Music. New Haven: Yale University Press, 1973.

Czeslaw Halski to Roman and Barbara Palester. Letter Collection from $29^{\text {th }}$ January 1947 to $27^{\text {th }}$ September 1951. Library of of Warsaw University: Polish Composers Archives, Palester Collection.

Josef Matthias Hauer Zwölftontechnik. Die Lehre von Den Tropen. Vienna: Universal Edition, 1926.

Zofia Helman, Roman Palester. Twórca i dzieto. Kraków: Musica Iagellonica, 1999.

Zofia Helman, Lech Dzierżanowski, and Piotr Maculewicz, Roman Palester. Warszawa: Biblioteka Uniwersytetu Warszawskiego, 2008 [Interactive Compact Disc].

Zofia Helman, "Roman Palester Muzyka kameralna i fortepianowa.” Trans. Mackenzie Pierce, booklet essay in CD Roman Palester. Muzyka kameralna i fortepianowa/ Chamber and Piano Music, performed by Jakub Tchorzewski (piano) and Duo Viennese (Warner Music 2016). 
Elżbieta Markowska, Jana Krenza pięćdziesiąt lat z batutą. Rozmowy o muzyce polskiej. Kraków: Polskie Wydawnictwo Muzyczne, 1996.

Thomas Nichols, "Preludes for Piano by Roman Palester; Sei Studi Per Pianoforte by Theo Bruins." Music Library Association 21, No. 3 (Summer 1964).

Jadwiga Paja-Stach, Polish Music from Paderewski to Penderecki. Kraków: Musica Iagellonica, 2010.

Roman Palester, Passacaglia. University of Warsaw Library: Polish Composers Archives, Palester Collection, 1953.

Roman Palester, Preludes for Piano. New York: Southern Music Publishing, 1963.

Roman Palester, Trois Sonnets À Orphée. University of Warsaw Library: Polish Composers Archives, Palester Collection, 1952.

Roman Palester, Stuch absolutny. Niedokończona autobiografia i listy z lat wojny. Edited by Zofia Helman. Kraków: Polskie Wydawnictwo Muzyczne, 2017.

Blake Parham, "The Invisible Man: Roman Palester and His Place in Post-War Polish Music.” University of Sydney, 2020.

"Roman Palester." Polish Music Information Centre (Polmic), http://www.polmic.pl/index. php?option=com_mwosob y\&id=23\&view=czlowiek\&litera=18\&Itemid $=5 \& l a n g=e n$. Accessed on 8 February 2015.

Polskie Wydawnictwo Muzyczne, "Certificate to Commemorate Roman Palester Receiving the First Post-War Music Prize of the City of Kraków in 1946." University of Warsaw Library: Polish Composers Archives, Palester Collection, $27^{\text {th }}$ October 1946.

"Protocols from the Senate Meetings." Kraków Academy of Music Archives: Catalogue Number: $90 / 27,31^{\text {st }}$ July $1945-28^{\text {th }}$ September 1949.

Richard Taruskin, "Preface-Music in the Late Twentieth Century." Oxford University Press. https://www.oxfordwesternmusic.com/view/Volume5/actrade-9780195384857-miscMatter-011008.xml. Accessed on $26^{\text {th }}$ June 2020.

Various, "Press Clippings Collected by the Composer and Held in His Personal Archives." University of Warsaw Library: Polish Composers Archives, Palester Collection, 1930-1990.

Michał Waszyński, Zabawka. Falanga Film Studio, 1933.

Arnold Whittall, The Cambridge Introduction to Serialism. New York: Cambridge University Press, 2008.

Związek Autorów i Kompozytorów Scenicznych to Roman Palester. Letter Collection from 1949 to 1979. University of Warsaw Library: Polish Composers Archives, Palester Collection. 
Blake Parham - recently completed a PhD entitled "The Invisible Man: Roman Palester", at the Sydney Conservatorium of Music on a full Australian Postgraduate Award. Previously he completed a Master of Philosophy degree researching Andrzej Panufnik at the University of Adelaide. He has held academic positions at the Avondale Conservatorium, the Wollongong Conservatorium, and currently works at the British School Warsaw. He has presented papers at conferences around the world including at the University of Glasgow, the Lithuanian Composers Union, the Fryderyk Chopin University of Music, in Kraków, Poznań, Brisbane, Sydney, Melbourne, and at the Polish Institute of National Remembrance. He has published articles with the Lithuanian Composers' Union, the Cambridge Scholars and worked on the revitalization of the Panufnik family Archives in London. Blake is also an experienced tenor having studied and performed in Australian, the u K, Germany, France, Poland, and China.

\section{BIOG RAM}

Blake Parham - ukończył niedawno rozprawę doktorską zatytułowaną The Invisible Man: Roman Palester [Roman Palester: Niewidzialny człowiek], przygotowaną w Konserwatorium Muzycznym w Sydney dzięki uzyskaniu pełnego stypendium rządu australijskiego na studia podyplomowe. Wcześniej uzyskał stopień magistra filozofii Uniwersytetu w Adelajdzie na podstawie badań nad życiem i twórczością Andrzeja Panufnika. Piastował stanowiska akademickie w konserwatoriach w Avondale i Wollongong. Obecnie pracuje w British School w Warszawie. Swoje artykuły prezentował podczas konferencji na całym świecie, m.in. na Uniwersytecie w Glasgow, w Związku Kompozytorów Litewskich, na Uniwersytecie Muzycznym im. Fryderyka Chopina w Warszawie, a także w Krakowie, Poznaniu, Brisbane, Sydney, Melbourne oraz w Instytucie Pamięci Narodowej. Jego teksty ukazały się w Związku Kompozytorów Litewskich oraz Cambridge Scholars. Wziął udział w projekcie rewitalizacji archiwum rodziny Panufników w Londynie. Blake Parham jest także śpiewakiem (tenor). Studiował śpiew i występował publicznie w Australii, Wielkiej Brytanii, Niemczech, Francji, Polsce oraz Chinach. 
ABSTRACT

\section{A New Home Leads to Compositional Evolution: Roman Palester's \\ Preludes for Piano (1954)}

Roman Palester (1907-1989) was one of the most promising and well-known composers in Poland during the inter-war period. On more than one occasion he was compared to the father of Polish contemporary music, Karol Szymanowski (1882-1937). ${ }^{1}$ As one of Poland's leading conductors Jan Krenz noted: "We met while working on the film Zakazane piosenki [Forbidden Songs]. I remember that Palester then came to Eódź in the halo of Szymanowski's successor. People would say 'this is the great Roman Palester."'2 Yet at the height of his fame, in 1951, he chose to leave his homeland and take up residency in the "free" West; subsequently he was cut off from Poland and his previous success.

The $2 \mathrm{O}^{\text {th }}$ century was a time of great cultural, political, and artistic change in Europe with a considerable number of divergent views about what constituted 'good' music. Terms such as modernism, nationalism, neo-classicism, socialist realism, serialism and atonality were all used regularly when discussing music and art. There ceased to be a clear or uniform musical style in Europe. Instead a cultural

\section{STRESZCZENIE}

Nowy dom sprzyja kompozytorskiej ewolucji: Preludia na fortepian Romana Palestra (1954)

Roman Palester (1907-1989) był jednym z najbardziej obiecujących i znanych kompozytorów w Polsce okresu międzywojennego. Niejednokrotnie porównywano go do ojca polskiej muzyki współczesnej, Karola Szymanowskiego (1882-1937). Jak wspominał jeden z czołowych polskich dyrygentów, Jan Krenz: „Poznaliśmy się podczas pracy nad filmem $\mathrm{Za}$ kazane piosenki. Pamiętam, że Palester przyjechał wtedy do Łodzi w aureoli następcy Szymanowskiego. Ludzie mówili: «to jest ten wielki Roman Palester»". Jednak w 1951 r., będąc u szczytu sławy, Palester zdecydował się opuścić ojczyznę i zamieszkać na „wolnym” Zachodzie, co mimo wcześniejszych sukcesów, w Polsce wiązało się $\mathrm{z}$ wyalienowaniem.

$\mathrm{xX}$ wiek był w Europie czasem wielkich zmian kulturowych, politycznych $\mathrm{i}$ artystycznych, $\mathrm{w}$ którym istniało wiele rozbieżnych poglądów na to, co stanowi „dobrą" muzykę. W dyskusjach o muzyce i sztuce używano regularnie terminów takich jak modernizm, nacjonalizm, neoklasycyzm, socrealizm, serializm $i$ atonalność. Przestał istnieć wyraźny i jednolity styl muzyczny w Europie, a zamiast

1 This is now a rather well-known fact and is often reported in the composer's biography. An example of this can be found in Polmic's entry for "Roman Palester," http://www. polmic.pl/index.php?option=com_mwosoby $\&$ id=23\&view=czlowiek\&litera=18\&Item$\mathrm{id}=5$ \&lang=en (accessed 8 February 2015).

2 Jan Krenz in Elżbieta Markowska, Jana Krenza pięćdziesiąt lat z batuta. Rozmowy o muzyce polskiej [Jan Krenz's Fifty Years with a Baton. Talks About Polish Music] (Kraków: Polskie Wydawnictwo Muzyczne, 1996), przekł. Julia Siudzińska-Parham, 81. 
polarisation emerged caused in large part by the division of the world into East and West during the Cold War. How did Palester, a Polish émigré, now residing in the West, effectively a composer in exile, adapt to these circumstances? What connection did his music have with avant-garde trends, anti-communist sentiments, traditional aesthetics, serialism, etc.? Was Palester's compositional voice affected by his defection?

In order to determine what Palester's post-defection compositional voice was and how it may have interreacted with events around him, this paper will examine one of Palester's pivotal compositions, Preludes for Piano (1954). These Preludes are a significant work in Palester's compositional output as they show a distinct shift towards a more comprehensive use of twelve-tone techniques. These techniques are employed in a variety of different ways and are often coupled with other techniques in order to create a style which is uniquely suited to Palester's compositional desires.

Key Words Roman Palester, Preludes for Piano, twelve-tone music, Polish music, Polish émigré tego pojawiła się kulturowa polaryzacja, spowodowana w dużej mierze podziałem świata na Wschód i Zachód w okresie zimnej wojny. W jaki sposób Palester, polski emigrant mieszkający na Zachodzie, a więc kompozytor na wygnaniu, przystosował się do tych okoliczności? Jaki związek miała jego muzyka z tendencjami awangardowymi, nastrojami antykomunistycznymi, estetyką tradycyjną, serializmem itd.? Czy emigracja wpłynęła na twórczość Palestra? W celu określenia, jaki był kompozytorski głos Palestra po decyzji o emigracji i jak mógł on współgrać z zachodzącymi wokół niego wydarzeniami, w niniejszym artykule przeanalizowana zostanie jedna z kluczowych kompozycji Palestra, Preludia na fortepian (1954). Preludia są w dorobku kompozytorskim Palestra dziełem znaczącym, ponieważ widać w nich wyraźny zwrot w kierunku bardziej wszechstronnego wykorzystania technik dwunastotonowych, stosowanych na wiele różnych sposobów i często łączących się z innymi $\mathrm{w}$ celu stworzenia stylu unikalnie dostosowanego do kompozytorskich pragnień Palestra.

Stowa kluczowe Roman Palester, Preludia na fortepian, dodekafonia, muzyka polska, polski emigrant 